University of Nebraska - Lincoln

DigitalCommons@University of Nebraska - Lincoln

PreColumbian Textile Conference VIII /

Jornadas de Textiles PreColombinos VIII (2019)

Centre for Textile Research

$6-2020$

\title{
Textil y territorio: sobre los tejidos intrincados de Poroma, Norte de Chuquisaca, Bolivia
}

Verónica Auza Aramayo

auzaveli@gmail.com

Follow this and additional works at: https://digitalcommons.unl.edu/pctviii

Part of the Art and Materials Conservation Commons, Fiber, Textile, and Weaving Arts Commons, Indigenous Studies Commons, Latin American Languages and Societies Commons, Museum Studies Commons, and the Other History of Art, Architecture, and Archaeology Commons

Auza Aramayo, Verónica, "Textil y territorio: sobre los tejidos intrincados de Poroma, Norte de Chuquisaca, Bolivia" (2020). PreColumbian Textile Conference VIII / Jornadas de Textiles PreColombinos VIII (2019). 24.

https://digitalcommons.unl.edu/pctviii/24

This Article is brought to you for free and open access by the Centre for Textile Research at DigitalCommons@University of Nebraska - Lincoln. It has been accepted for inclusion in PreColumbian Textile Conference VIII / Jornadas de Textiles PreColombinos VIII (2019) by an authorized administrator of DigitalCommons@University of Nebraska - Lincoln. 


\title{
20
}

\section{Textil y territorio: sobre los tejidos intrincados de Poroma, Norte de Chuquisaca, Bolivia}

\author{
Verónica Auza Aramayo
}

\section{Resumen}

La presente propuesta pretende comprender cómo el sistema territorial andino está manifiesto en el lenguaje visual de los tejidos; específicamente en el estudio de los tejidos de Poroma, Norte de Chuquisaca, Bolivia. Cultura andina caracterizada por una larga historia que evoca diversos movimientos y procesos multiétnicos, que estableció, en un valle de características tórridas, una auto denominación cultural que la designa como «llameros», vale decir, gente que desde las altas punas antiguamente y hasta la década de 1980 se desplazaba con sus caravanas de llamas, marcando un mercado de bienes a lo largo de la cordillera. Esta forma de nombrarse y de ser nombrados evoca conocimientos, desplazamientos y el manejo de la geografía y de los territorios que las comunidades del sur andino de Poroma dispusieron a través de su historia para habitar este espacio y para forjarse un sentido de pertenencia cultural.

Habida cuenta de ello, se trata de comprender la relación que se establece entre el complejo sistema territorial y el signo textil de Poroma, para comprender no va cómo el lenguaje visual ofrece, precisamente, a través de las representaciones textiles de diseños, patrones, simbologías, formas y sentidos cromáticos de la vestimenta, la identidad multiétnica y entreverada de esta cultura.

Palabras claves: Textiles andinos, Chusquisaca, Poroma, territorialidad, llameros, semiótica.

\begin{abstract}
The present proposal aims to understand how the Andean territorial system is exhibited in the visual language of cloth; specifically in the study of the textiles from Poroma, northen of Chuquisaca, Bolivia. This Andean culture is characterized by a long history looking back on diverse movements and multi-ethnic processes, which established, within a very warm valley, a cultural self-designation that designates them as «llameros» meaning people who from the high plateaus since old times until the eighties of the last century moved with their caravans of llamas, defining a market of goods along the mountain range. This way of naming themselves and being named by others evokes knowledge, patterns of movement and expertise in the geography and territories that communities of the Andean south of Poroma managed throughout their history, in order to inhabit this space and forge for themselves a sense of cultural belonging.

Given this framework, the aim is to understand the established relationship between this complex territorial system and the textile or semiotic of Poroma, to realize how visual language offers, particularly, through textile representations including designs, patterns, symbolism, forms and chromatic sense of clothing, the multiethnic and mixed identity of this culture.
\end{abstract}

Keywords: Andean textiles, Chusquisaca, Poroma, territoriality, llama caravans, semiotics.

\section{Résumé}

La présente étude prétend comprendre comment le système territorial andin se manifeste dans le langage visuel des tissus, particulièrement dans l'étude des textiles de Poroma, au Nord de Chuquisaca, en Bolivie. Cette culture andine se caractérise par une longue histoire reflet de divers mouvements et processus multiethniques, qui a établi, dans une vallée très accueillante, une autodénomination culturelle. Ses habitants sont désignés comme "llameros", les personnes qui, autrefois et jusqu'aux années 1980, se déplaçaient avec leurs caravanes de lamas, définissant un marché de biens le long de la cordillère. 
Cette façon de se nommer et de nommer par autrui évoque à la fois les connaissances, les déplacements et le maniement de la géographie et des territoires que les communautés du sud andin de Poroma ont répandus à travers leur histoire pour habiter cet espace et se forger un sentiment d'appartenance culturelle.

Compte tenu de ce contexte, le but est de comprendre la relation établie entre ce système territorial complexe et la sémiotique des tissus de Poroma afin de comprendre comment le langage visuel reflète, en particulier grâce aux représentations textiles incluant conceptions, modèles, symbolismes, formes et sens chromatiques des vêtements, l'identité multiethnique et variée de cette culture.

Mots-clés: Textiles andins, Chusquisaca, Poroma, territorialité, caravanes de lamas, sémiotique.

Empiezo indicando que este ensayo se basa en el testimonio de la tejedora de Poroma: Claudina Torres ${ }^{1}$. Convengamos que toda destreza textil expresa el pensamiento y la creatividad de las tejedoras andinas, así, constituye un sistema de sentido que se erige cuidadosamente al entrecruzar hilos en órdenes y diseños tejidos; sí, todo tejido es un sistema de sentido visualmente plasmado, estéticamente emotivo y simbólicamente exuberante de un modo de ser y de estar en el mundo. En definitiva, en el espacio; en definitiva, y a partir de lo cual, podemos asumir al textil como un arte y como un arte femenino de habitar el mundo.

Cuando miramos a los textiles andinos, es dable pensar que no solamente estamos frente a vestimentas y prendas vistosas, los textiles en el mundo andino no solo son ropajes ornamentados o decorados para vestir los cuerpos, sino y sobre todo los textiles expresan y materializan un lenguaje visual cuya belleza de sus signos definen y recalcan identidades culturales, es decir, los modos de ser andinos.

De tal manera, se trata de entender el arte textil como expresión vívida y sentida que las tejedoras ofrecen como grafías de identidad, desde lo simbólico de sus diseños culturales, desde sus estructuras que representan el habitar los espacios de la territorialidad andina, desde el sentido de sus formas, desde la complejidad cromática que sustentan, en fin, desde la semiología de su lenguaje plástico destinado histórica y culturalmente a envolver, proteger, vestir y de dotar de identidad a los cuerpos. En otras palabras, un lenguaje de piel, que solo podemos conocerlo y comprenderlo a través de sus creadoras, las tejedoras, pues son ellas y sus pensamientos, sus destrezas, sus intelectos y sus capacidades sensibles hacia los signos vertidos (difundidos, volcados) en los hilos, las que por muchos siglos, han dotado de sentido de identidad y de sentido estético al mundo andino a través de los textiles.

El arte textil que toda tejedora brinda en sus prendas, hace que cada textil exprese una carga simbólica específica, una suerte de "espíritu, cuerpo y ser", por lo tanto una existencia, un sentido y una transcendencia, así cada prenda tejida refiere a una forma de habitar el mundo además de un conocimiento de quien lo habita, las tejedoras organizan la urdiembre y la trama desde la destreza y proliferación de sus lenguajes visuales, brindando sentido en cada uno de los hilos empleados, en el orden de los colores y sus alternancias, en la definición de los diseños y las soluciones formales que desde tiempos precolombinos y hasta la fecha marcan la distinción de cada cultura en el mundo andino, de ahí, lo axial y el poder de la imagen que el arte textil nos sigue ofreciendo día a día en Bolivia.

Antes de empezar debo mencionar que este análisis se basa en los estudios, imprescindibles de Verónica Cereceda, Denise Arnold, Sophie Desrosiers y Teresa Gisbert.

Precisemos. Todo tejido en el mundo andino contiene una gran profusión de lenguajes visuales, los cuales contienen y expresan una emoción estética indiscutible en el diseño de sus imágenes, en sus órdenes cromáticos y en sus estructuras y técnicas que los tejen. A partir de ello, se trata de comprender y explicar el sentido que transmiten y contienen los tejidos desde "adentro", como establece Verónica Cereceda (2017); vale decir, desde sus propios lenguajes y sistemas de significación; tarea difícil debido a las muchas espesuras que el tiempo y la gramática visual del textil han tenido que sobrellevar las sin comunidades andinas a lo largo de la historia. Sin embargo, deshacer lo cifrado de este lenguaje visual es posible en la medida que sepamos reconocer la labor creativa de las tejedoras, el sistema de significación que las tejedoras plasman en sus tejidos y a su vez las representaciones de mundo que subyacen en cada uno de los textiles, es por ello que cada una de mis investigaciones parten y caen en los saberes de primera mano que las tejedoras me brindan, como es este ensayo que realice con el testimonio de Claudina Torres. Sabemos que cada prenda tejida: awayos, las llikllas, aqsus, taris y fajas; que las mujeres andinas mantienen en sus vestimentas, las distingue y las engalana en fiestas, rituales y vidas cotidianas. Así, en cada prenda tejida, hoy todavía late y se manifiestan concepciones, pensamientos y modos de ser y de estar, lo cual 
nos lleva a volcarnos a su "interior" intentando comprender sus propias estructuras formales y significantes expresadas en la composición del orden manifiesto de sus colores, formas, diseños y estéticas.

Al conversar con Claudina, ella me transmite el alcance del lenguaje visual que dominan en Poroma, así, con ella, podemos permitirnos conocer y reconocer los sistemas de significación que se manifiesta en cada uno de sus diseños, es a través de ella que logramos advertir las profundidades históricas de estos lenguajes, la profundidad en el tiempo de cada uno de sus diseños y sus órdenes cromáticos, a la par que podemos advertir las sendas de transformación para su remezón y sus actualizaciones formales; así, Claudina nos permite abordar la espesura semántica de su arte textil, que pervive y se mantiene vigente.

Antes de continuar por la singularidad de los tejidos de Poroma, señalo que mis estudios de la sociología del arte textil se basan en el análisis e interpretación del lenguaje visual que nos ofrece y de las explicaciones que sus creadoras me dan de los mismos, así, es relevante precisar:

- la estructura textil: diseño, colores, espacios de cada prenda tejida,

- los aprendizajes y el desarrollo de las técnicas que se aprecian en cada una de las destrezas textiles de las tejedoras,

- de los caminos de conocimientos que las tejedoras sortearon en sus vidas para afinar la técnica y el dominio de los hilos en urdiembres y tramas; quehacer, obra, práctica, ejercitados una y otra vez para dar lugar a la creación femenina del arte textil.

Abordar cada una de las piezas del universo textil andino, es aprender su lenguaje plástico, su sintaxis visual, la gramática de signos; lo cual implica, más allá de su sentido de identidad, comenzar a entender en su lenguaje visual, en su imagen, la expresión artística plasmada (o tejida) en los siguientes elementos:

- El orden cromático y la significación del color de cada textil;
- la definición de bandas entre espacios de pampa ${ }^{2}$ y espacios de pallay o salta ${ }^{3}$;

- la demarcación de espacios: centros, límites y disposiciones de franjas o bandas;

- la estructura del color que permite la construcción de contrastes, de fondos y de figuras, que dan paso a patrones entre lo oscuro y lo luminoso (y a la inversa) y la sucesión de tonalidades diferentes que realzan las bandas y sus extensiones;

- la composición de diseños que proyectan animales, ríos, lagunas, plantas, estrellas, fuerzas de la naturaleza y órdenes culturales, diseños que en definitiva, evocan los sistemas de significación de cada uno de los territorios y de las diversas culturas del mundo andino;

- la expresión simbólica y el singular sentido visual que cada tejido transmite como pieza terminada.

Volcando la mirada al pasado y siguiendo el registro iconográfico legado en la temprana colonia por Guamán Poma (1615), se puede apreciar la distinción textil de las diferentes culturas que habitaban el territorio andino. Quizá las láminas que retratan a las Coyas o reinas andinas con la vestimenta que primaba en esa época, son las que mejor nos permiten apreciar la importancia no sólo de cultural, sino también política que se establecía con las prendas tejidas. Vemos llikllas que definían el prestigio, la soberanía y con ella la territorialidad desde el sistema de la vestimenta, e iconográficamente, dentro del incario. Lo primero que muestran estas láminas es la suerte de epítome de feminidad en los Andes ${ }^{4}$ que es el tejer. En la lámina 23, vemos a una mujer con huso en la mano, hilando, ella, dice Guamán Poma, expresa a las mujeres que tenían 33 años y eran consideradas como doncellas vírgenes "perpetuas para el sol, la luna, los templos, los dioses y para el inca”. En la imagen la vemos con el atuendo completo que esas doncellas vestían: aqsu, que era el vestido originario que las mujeres andinas

2. La pampa es el espacio de un sólo tono que carece de diseño y dibujo.

3. Pallay en quechua, salta en aymara, son los verbos empleados para definir la técnica que introduce diseños y dibujos en la trama de los textiles. 4. Varios estudios señalan que el tejido marcaba la distinción genérica de la feminidad en los Andes, lo sugiere estructuralmente John Murra (1975) cuando habla de la función del textil en el mundo andino antes de la llegada de los españoles o Irene Silverblatt (1990) y Maria Rostowrowski (2000) que de un modo más acucioso se detienen en el universo femenino que dependía en las mujeres andinas antes y después de la colonia, estas dos autoras nos llevan a los universos sagrados, de ritual, de territorio, de poder y de omisión que las mujeres en los Andes fueron definiendo con el paso de los diversos regímenes dominantes que les tocaron vivir. Tema complejo y polémico, del cual podemos considerar, para este ensayo, la función de género que el tejido instaló en las acllawasi del incario y el trastoque que la empresa colonial estableció en el textil como tributo y explotación de las mujeres aún las sucesivas prohibiciones que se dictó sobre esta destreza andina, haciendo que el tejido, el rol textil y las creaciones de las tejedoras perdure con un lenguaje que ha sufrido un sinfín de variaciones y adecuaciones en sus signos, en su gramática, en su sistema de vestido y en su impacto visual, llegando hasta nuestros días. Paradoja histórica que no se puede dejar de considerar para entender el alcance comunicacional que la plástica de los textiles sigue transmitiendo en los diferentes paisajes y escenarios actuales. 


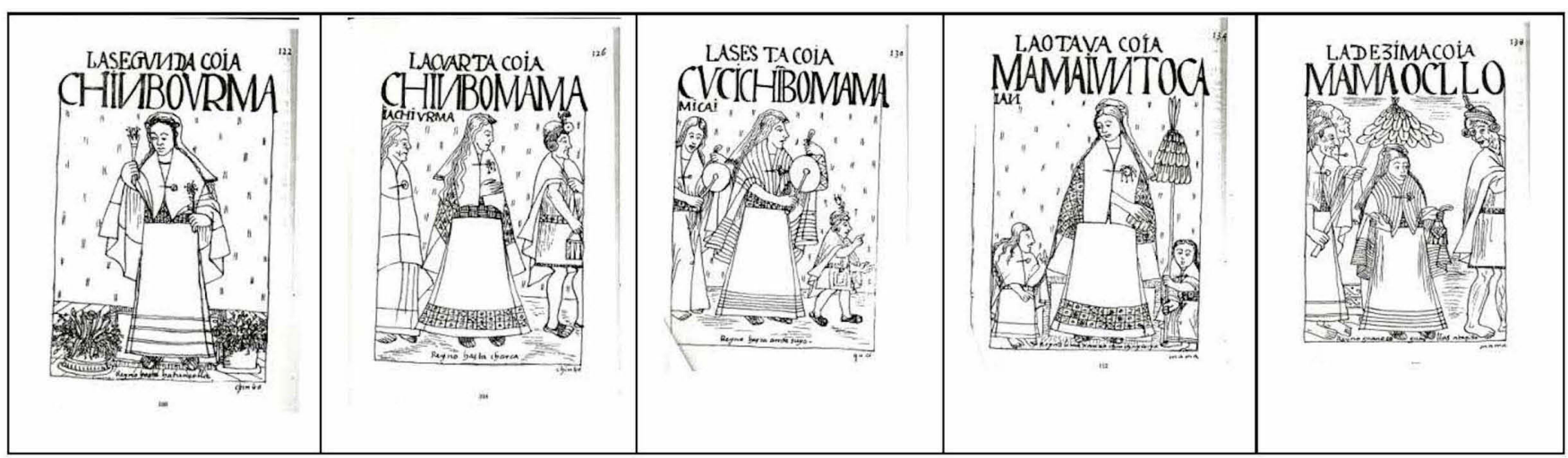

Ilustración 1: Láminas de Collas de la Crónica de Guamán Poma de Ayala, 1615.

vistieron hasta el siglo XVIII, una faja ataviada por muchos diseños ${ }^{5}$, lo cual connota una verdadera destreza textil que a estas mujeres las caracterizaba y una llijlla sujetada con un topu, llijlla que a lo largo de la crónica Guamán Poma marca la distinción de las reinas y sus estatus expresado en los diferentes de colores y diseños que exhibían. Todo ello nos da cuenta, que al menos hasta el inicio de la colonia, existía un sistema de vestimenta en el cual las mujeres mostraban su posición de poder desde el dominio textil que vestían. Siguiendo el repertorio iconográfico de Guamán Poma, encontramos una secuencia de Reinas o Coyas, que es muy explícita para entender como la vestimenta textil exponía las jerarquías y las distinciones que las mujeres y también los hombres advertían en la usanza de todas las prendas tejidas que vestían. Se observa que una de las piezas claves en la vestimenta de las Coya era la llijlla, que son prendas cuyo fin era la exposición, son las piezas que de todo el atuendo saltan inmediatamente a la vista; en definitiva, vestir estas llikllas establecía y remarcaba el poder de estas mujeres, su poderío como reinas (Ilustración 1).

Con estas láminas comprendemos que las llikllas eran las prendas indispensables para definir a estas mujeres como reinas destinadas a los ámbitos de poder y ejercicios dominantes de lo sagrado y lo social.

Para profundizar, añado a este universo a este universo de sentido que sostienen y construyen las tejedoras y sus creaciones textiles, la noción brindada por Arnold, et al (2007) que nos enseña a entender los textiles de la región con la siguiente premisa: lo corporal del textil, lo territorial, lo bélico, lo religioso y sagrado, lo cognitivo, lo textual, lo subversivo y lo femenino del copioso lenguaje plástico y visual de las prácticas textiles vivas que se manifiestan, en las comunidades andinas de Bolivia. Siguiendo ambas nociones he procurado comprender en cada prenda tejida estos niveles de sentido y de significación, perfilando en cada una de sus imágenes estas concepciones que se esmeran por reconocer en cada expresión textil las relaciones político-históricas que sostienen las comunidades existentes. Siendo así, cada diseño encontrado y detallado, contiene un pasado que convoca a comprender el sustrato arqueológico que late en su simbología, el régimen territorial que motiva su mensaje, la trayectoria etnográfica presente en su estructura textil y el lugar en lo que Arnold (2007) retomando a Cereceda (2017) y Dransart (1996) expone y define como la historia del arte del textil andino.

Con todo esto en mente es posible advertir los horizontes de la memoria textil, aquella que está presente en cada técnica y tejido expresada de manera continua o con variantes, sí, traer el pasado, saber cómo las hijas o las nietas recuerdan y actualizan los modos en que tejían sus abuelas, quiénes les enseñaron, para poder entender los caminos visuales, estéticos, textiles y culturales por donde ellas tejen en el presente. Ver cómo tejen ahora y reconocer los motivos por qué lo siguen haciendo, evoca los imperceptibles territorios por los cuales las interrelaciones o los roces e influencias con las otras dinámicas textiles siguen vivas. Todo ello, nos procura la certeza de un presente activo y nos brinda la manifestación más amable del pasado para el porvenir, ya que ellas, al seguir tejiendo esperan y mantienen las expectativas que auguran un presente y un futuro a la producción textil y al rol creativo, simbólico, femenino y cultural que viene con ella.

En ese sentido, y realizando una suerte de ejercicio cartográfico (como se vera en las ilustraciones: 3 - 14 sobre la variedad textil de Poroma; realizadas en base a las fotografías del libro: Diseño de los textiles de Poroma. Asur, 2010),

5. Esta prenda todavía se usa y ostenta notoriamente por las mujeres de Charazani, a diferencia de la mayor parte de las zonas andinas, donde las fajas no están a la vista. 
podemos construir una imagen cual topología espacial de la producción textil, en la cual podemos ver la geografía del arte textil y ahí percibir y entender la memoria visual de las tejedoras, los signos estéticos de sus identidades y sus manifestaciones tejidas que no cesan de erigir estas representaciones como un lenguaje visual que marcó, como marca, la transcendencia y la diferenciación cultural por y para los Andes.

Siendo parte de esta geografía textil, los tejidos de Poroma traducen la fuerza y la emoción estética viva que en los Andes, desde tiempos inmemoriales, ha tenido no solo la virtud de marcar distinciones culturales de cada una de las identidades étnicas, sino también la potencia de modificar las realidades sociales, construyendo y luchando por nuevas apropiaciones del espacio o por recomponer el devenir comunitario perdido y así, una vez más, lograr que el espacio sea habitable y se convierta en territorio, Poroma y sus tejidos, exponen francamente todo ello, en su devenir histórico de la puna al valle y en sus signos textiles multiétnicos, diversos, a la vez novedosos y a la vez ancestrales, donde como más adelante se verá, el aywira de Bertonio (1984 $\{1612\})$, es posible también advertirlo en los jatun ch'aska chawpimpi ch'uru ñawiyuq y los elefantes de las llikllas de Claudina Torres.

El universo textil trasmite visualmente tanto el modo político como la manera estética de habitar el espacio: "Los lenguajes plásticos de los colores y las formas son la materia para que la sociedad [andina] exprese sus propia y específica percepción sobre su sociedad y su cultura, sus tiempos $y$ sus condiciones de existencia" (Martínez, José Luis, 1992). Es por ello que los textiles son como topografías portátiles que se hallan indisolublemente asociados a la naturaleza, a los ciclos del cosmos y a las intervenciones culturales que definen y hacen habitable al territorio. En definitiva, la materialidad entretejida del textil nos trasmite una suerte de topografía visual, una cartografía textil, donde destacan cada uno de los lenguajes plásticos y diferenciales plasmados en los tejidos. La imagen en mi mente queda cual distinción visual que respeta los sentidos y diferencias de cada uno de estos paisajes culturales, son golpes a la vista y a los sentidos, extraordinario sistema simbólico, que se nos brinda a través de la viva usanza andina del tejido, una cultura textil que convoca desafiantemente a ahondarla.

\section{Del arte textil para habitar el territorio: los hilos llameros de Poroma.}

Detengámonos en los orígenes de la complejidad étnica de Poroma. La problemática del territorio en los Andes explicada por John Murra (1975), Thierry Saignes, (2015) y, recientemente, Vincent Nicolas (2015) nos permite comprender la importancia y transcendencia de las modalidades políticas y culturales que los pueblos andinos han desarrollado desde tiempos precolombinos para habitar y hacer habitable el espacio, a partir del establecimiento de los límites entre comunidades y a partir de la compleja dotación de sentido que estas culturas realizan sobre la accidentada geografía que cruza la cadena de montañas de elevadas punas, cálidos valles y expansiones subtropicales ya amazónicas en sus estribaciones.

Para entender el vínculo que se da entre textil y territorio, tenemos que pensar en aquellos mecanismos para habitar el espacio, que el mundo andino, se fueron superponiendo a lo largo de la historia en sus sentidos y estrategias precolombinas, coloniales y republicanas. Hecho complejo que Verónica Cereceda (2010), interpreta a cabalidad para el caso de Poroma:

“... para entender lo que ahora sucede en Poroma, que los grandes ayllus antes de la llegada de los españoles y en los tiempos de la colonización, poseían tierras que no eran continuas, es decir, cada ayllu, los Macha, por ejemplo, o los que ahora como T'inkipayas que no se llamaban todavía de ese modo, u otros, buscaban tener acceso a distintos climas y a distintos productos. Es así como ayllus de la puna, poseían chacras en ambientes más bajos para poder cultivar maíz, y no sólo quinua y las variedades de papa o criar llamas, que son las posibilidades de las alturas... El ir y venir de la población indígena a localidades que no eran los territorios centrales del ayllu, donde algunos grupos se quedaban por tiempos largos para cuidar y recolectar cosechas, no fue bien visto por la administración española durante la colonia. Exigieron que cada persona tuviese residencia fija donde se le podía ubicar para cobrar tributo, especie de impuesto que debían pagar todos os que vivían en el campo por el uso de sus tierras. De este modo se fue frenando cada vez más el acceso de los ayllus, como tales, a sus chacras en lugares más cálidos. Luego ya fue tarea de las familias como unidades domésticas y no de los jilaqatas o mallkus, continuar trabajando en esos lugares que les habían pertenecido desde tiempos ancestrales o fijar definitivamente su hogar en ellos, ya sin regresar necesariamente al territorio central de su grupo natal.

Así se fue poblando Poroma con gente venida de diferentes partes... Habitan en este municipio (de Poroma) gente venida de T'inkipaya, de Marcha, de Pocoata, de Laymi, y otros llegados de más cerca como Janina, Ravelo, como muchos que se consideran originarios de estas tierras o han olvidado 
su origen. Poroma es así un mosaico multiétnico que testimonia las prácticas culturales que tenían los antepasados -abuelos de los abuelos de abuelos- de cultivar distintos climas y distintos niveles de nuestro territorio para obtener directamente todos los productos que les hacían falta para su subsistencia...”.

\section{Ilustración 2:}

A partir de este mapa étnico cultural que nos ofrece ASUR (2010), podemos advertir que los grupos culturales que hoy se encuentran en Poroma, son específicamente: Llameros de Potosí, J’alqas, y Q'aqchitus y Mestizos en menor número. Antes de detenerme en el grupo de los Llameros, veamos la compleja diversidad textil y cultural de Poroma, a partir del libro: Diseños de los textiles Poroma. Investigación y fotografías. ASUR, 2010, el cual, como se puede apreciar nos expone de modos singulares la variedad y diversidad textil del complejo Poroma y la complejidad de este diseño textil (Ilust. 3).

Con este mosaico textil en mente, detengámonos en el diseño textil de Llameros de Poroma. Siguiendo las palabras de Verónica Cereceda (2010), los Llameros tienen su origen en las culturas de puna, muchos de ellos dicen haber llegado de T'inkipaya, dato que está corroborado por los propios t'inkipayas, otros provienen de Macha, de Killakas, de Urmiri, de Laymi, de Pocoata, indudablemente de las punas de Potosí y Oruro. Lo importante a tener en cuenta es la concepción que se manifiesta de parte de los pobladores de Poroma cuando evocan el pasado de los llameros y dicen: "Los llameros son del lado de T'inkipaya, no son oriundos de estas tierras. Siempre se trasladan de un lugar a otro, de otro lado vienen y van...”. Palabras de Jerónimo Aguilar Guzmán, citado en Cereceda (2010).

Por su parte, por ejemplo, Moíses Puma, afirma: “... me han traído cuando era bebé, en la cara de mi mamá... dicen que andaban de nómadas..." citado en Cereceda (2010), o el relato de Gabriel Quintín, quien comenta que su abuelo era de Jukumani y dice "según comentarios se escucha que ellos habrían venido de la puna y por eso tendríamos parentesco en la puna. En la puna hay una cultura similar a la nuestra, aunque no es igual, sino varía en alguna medida. Fíjese las figuras no son igual, las de ellos tienen más colores amarillentos como los de T'inkipaya, lo propio pasa con los tejidos de Macha y Tumaykuri, son distintos los tejidos. Mi persona ha ido por esos rumbos comparando, con mi ropa queriendo igualar, pero no se asemeja en lo absoluto. Es distinto, un poco oscuro, no puedo describirlo. De ellos sus colores son más vivos..." citado en Cereceda (2010). Otro atributo que vale la pena advertir que también a los llameros los llaman "tulqas", o sea, los yernos que vinieron de la puna

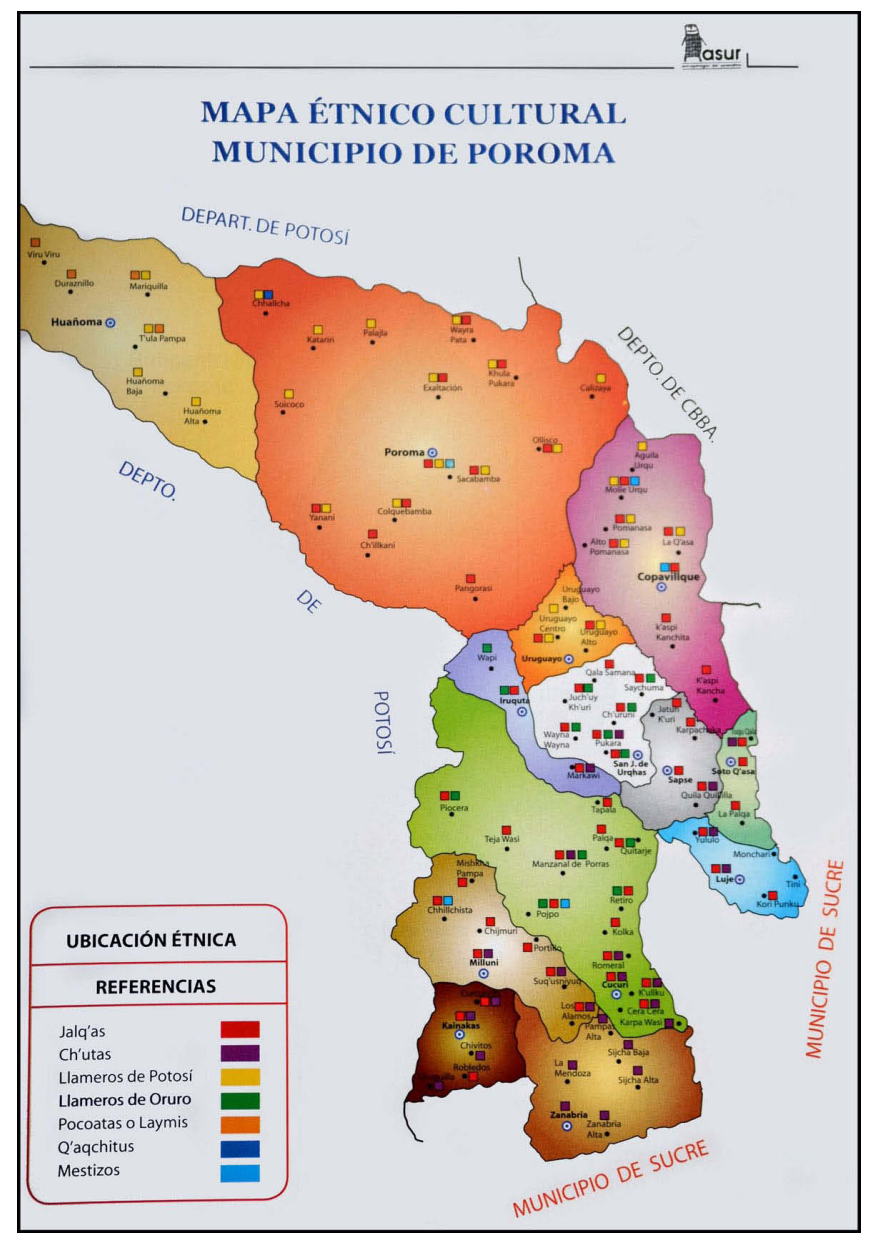

Ilustración 2: Mapa de Poroma. Poroma: Composición étnica y culturas. ASUR, 2010. Pág. 33.

para casarse y se dice que tienen cualidades de curanderos, porque "hacen soltar los ánimos".

Para finalizar, el origen j’alqa, quizá es el que mejor explica la distinción textil que se evidencia en los tejidos "un poco oscuros” Poroma, así Valerio Vázquez afirma: “... Antes a ellos los llamaban 'purirantes', mi padre había sido uno de los luchadores por la libertad... a los que se llamaban 'puriq runa' o 'antiguos caminantes'. Este grupo de luchadores se organizó justamente en zonas Jalq'as de Poroma, antes de la Reforma Agraria. Era gente que caminaba de noche, de comunidad en comunidad, hablando de la necesidad de recuperar las tierras de origen que las Haciendas se habían apropiado. Un símbolo de esta relación ancestral con las tierras eran los textiles. Las antiguas imágenes Jalq’a, con khurus (animales extraños y silvestres) indomables, dispuestos con gran libertad en el espacio del pallay (diseño), representa ese mundo sin constricciones que este grupo de los puriq anhelaba como meta de su lucha. Los textiles jalq'a fueron así, como una bandera de los antiguos caminantes" (Cereceda: 2010). 

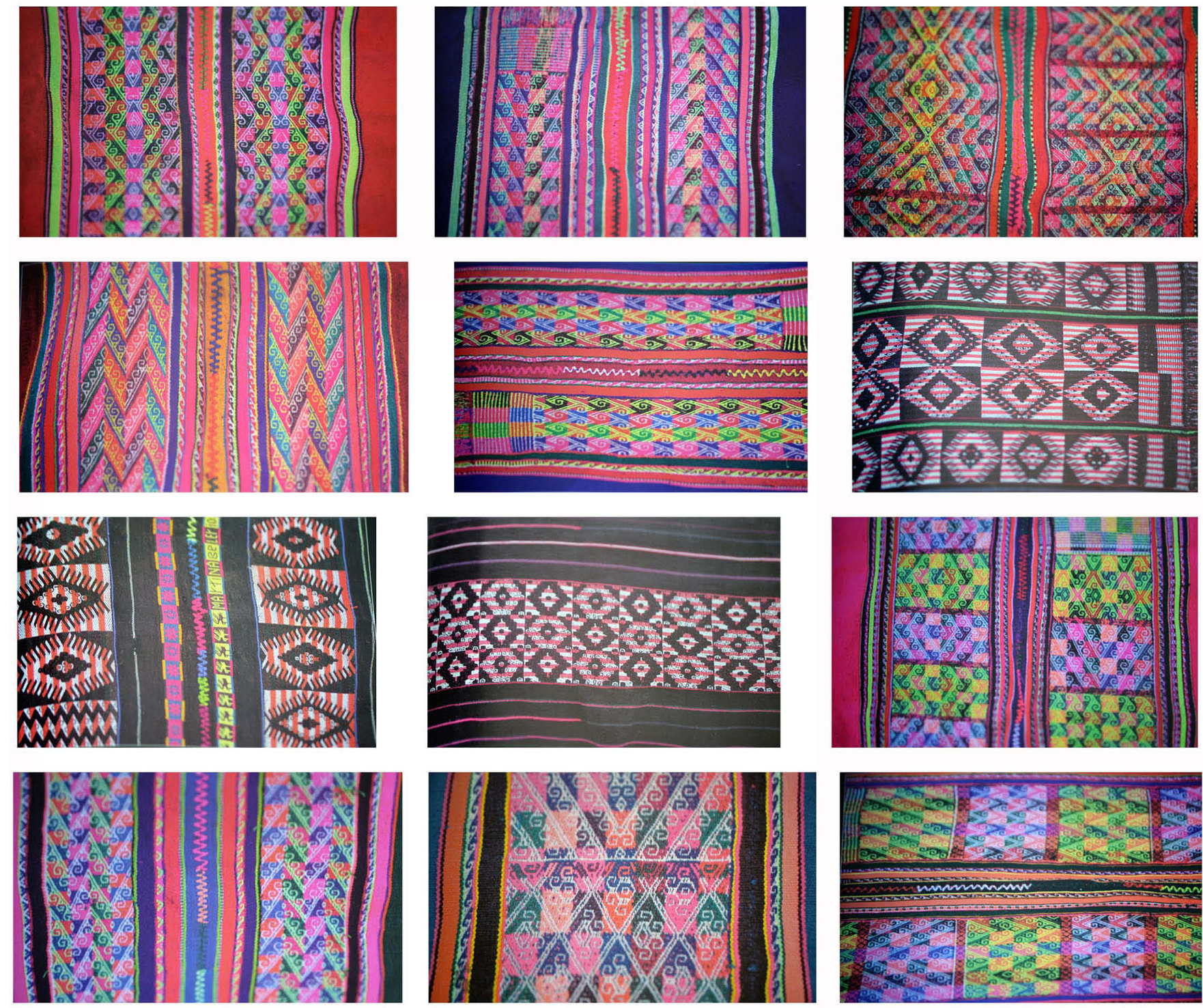

Ilustración 3: Llikllas de Mariquilla, Duraznillo, Viru Viru y Huañoma Alta, del libro: Diseños de los textiles Poroma. Investigación y fotografías. ASUR, 2010. Págs. 7, 33, 39, 41, 73, 83, 107, 109 y 113.

Vemos que este origen de puna y el caminar por la noche, el caminar luchador, por sobrevivencia, del bajar de las alturas al valle en procura de tierras propias, de distinciones propias, de libertad, de habitar esa frontera estética entre el cielo y los colores vivaces de la puna, siendo un poco oscuros, teniendo como bandera o meta lo indomable del manqa pacha jalq'a, hace definitivamente que las tejedoras siendo "llameros de Poroma" hoy en día, nos traigan en su creación textil ese mismo sentido intrincado, que afectivamente desde el textil procura ir y venir en un andar sin amo, en un andar libertario, como lo hicieron los abuelos luchadores, dando pasos en la noche, de comunidad en comunidad, esos antiguos caminantes que forjaron caminos, algo desviado del constreñido republicano, ese andar nómada en procura de tierras propias para habitarlas a su modo.

Visto así, la simbología y el arte textil en Poroma, solicitan una apertura visual y mental para abordar todos los sentidos de la imagen que en ellas funcionan. De ese modo, con los tejidos de Poroma tenemos que conjugar la energía de las dinámicas étnicas, sus flujos, sus desplazamientos y enfrentamos de entrada con un signo intrincando, complejo y singular que continúa dando vigencia a un lenguaje visual que evoca los procesos imperceptibles, constantes y mezclados de esta cultura.

Al interior de este complejo cultural cabe también preguntar: ¿cómo el lenguaje y la memoria visual de los tejidos 
de Poroma expresan en el orden de sus hilos, su cromática y sus diseños esta cultura móvil, de caravanas, de trajines? Y ¿será que la cultura textil, su alcance visual y afectivo que todavía sienten las tejedoras por las prendan que tejen, congenia y se despliega con la espesura de un saber que requiere dominar el espacio y los recorridos por el territorio? Estas cuestiones me hicieron reflexionar sobre las superposiciones, imbricaciones, tensiones y pugnas que laten en el arte textil y la simbología creada por las tejedoras de Poroma hoy en día.

\section{Claudina Torres: De la puna al valle y "se teje de tres".}

Como ya mencione, la presente propuesta pretende comprender el complejo sistema territorial andino a partir del lenguaje visual de los textiles de Poroma. Para ello, me apoyare en la conversación que sostuve con Claudina Torres, tejedora de la comunidad T'ula Pampa, Poroma. Claudina, actualmente tiene 29 años y vive en la ciudad de Sucre desde hace 7 años. Claudina teje desde sus 7 años y a los 14 hizo su primer aqsu y lliklla, en la fotografía Claudina nos muestra su lliklla; ella nos cuenta que aprendió a tejer con su mamá y hasta el día de hoy disfruta tejer con sus amigas, paisanas, comadres y primas en la ciudad (Foto 1). Viaja constantemente a su comunidad y me dice que aunque por sus guaguas se vino a Sucre a ella le encanta vivir en el campo, al igual que ella su mamá, nunca dejaron de sostener su doble residencia: urbana y rural.

Lo primero que se tiene que mencionar es que esta comunidad presenta dinámicas culturas venidas de Pocoata y Laymis, ambas culturas "beligerantes" en la región nor chuquisaqueña. Este arte textil evoca precisamente la singular transcendencia y antigüedad de los trajines en los Andes, pues mantiene y desarrolla sistemas textiles con fuertes cargas simbólicas y semánticas que se expresan por los diseños, los usos de listados simétricos en sus bordes, la estructura que la distingue cada que establece la pampa binaria y el kimsa pallay, lo cual denota una característica central para distinguir a estos tejidos en todo el entorno cultural que los rodea (Foto 2). En los cuales destacan la importancia de los desplazamientos espaciales para el arraigo y la apropiación del territorio. El diseño trae entre sus hilos, el sentido visual de un territorio habitado por los andares de los «llameros» y cada uno de los recorridos que definieron el accionar cultural de los «antiguos caminantes» por un territorio libre y propio.

La forma de auto nombrarse «llameros»y de ser nombrados «llameros», sin duda, evoca todo el caudal del conocimientos, desplazamientos en el manejo espacial, de la geografía, y de los territorios, propio de las comunidades del sur andino (Foto 3), que a lo largo de los siglos desarrollaron y

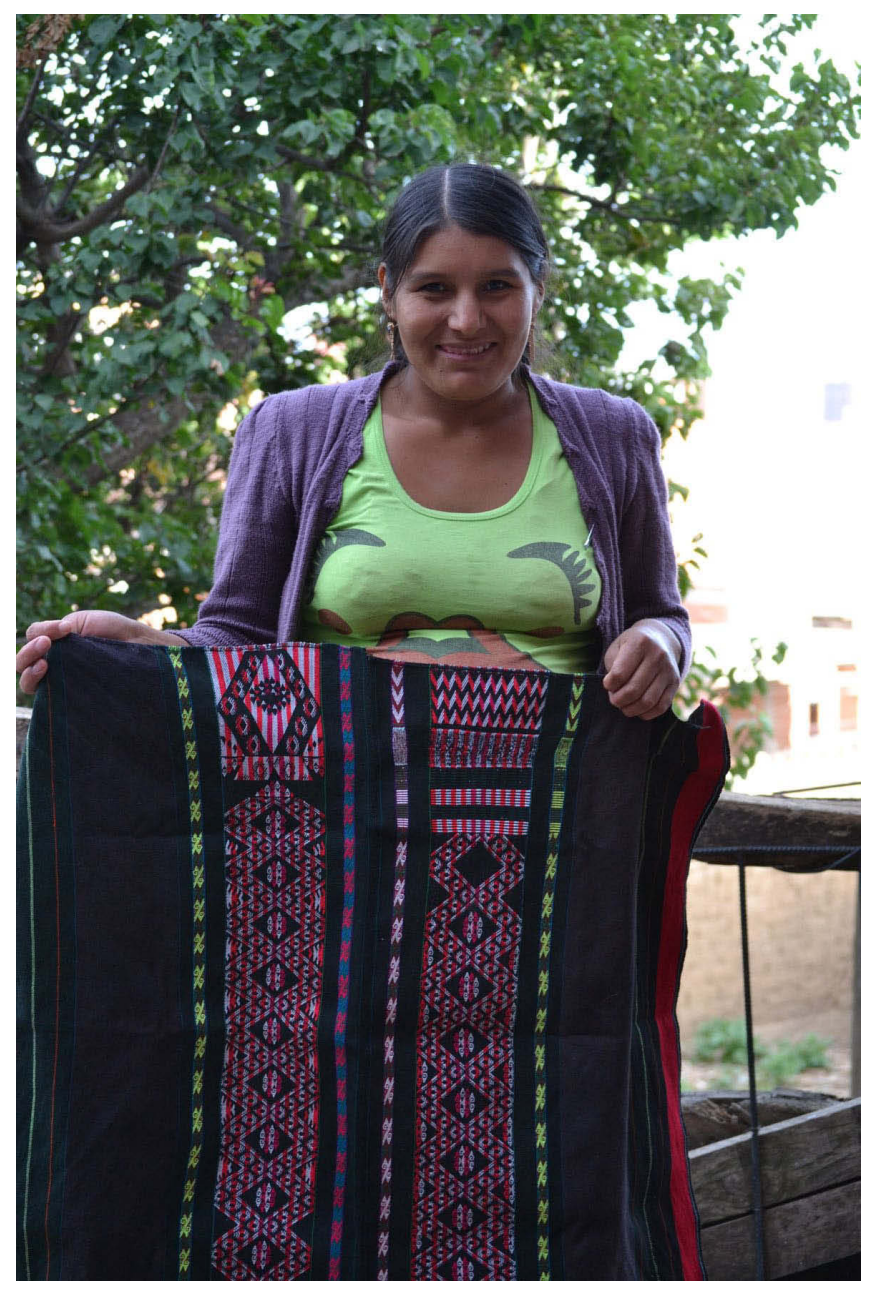

Fotografía 1: Claudina Torres. Fotografía de Verónica Auza Aramayo.

ejecutaron un modo de habitar el espacio diverso y expansivo, diseñado además para dotar de un sentido de pertenencia a los pueblos andinos.

Este sistema territorial, además de las complejas prácticas culturales, sociales y políticas, estuvo desde siempre acompañada por la sofisticada trama del lenguaje visual del textil, así encontramos que cada cultura, en el amplio y accidentado territorio andino, configuro su propia estructura visual para su distinción a partir del signo textil (Foto 4), precisamente y sobre todo desde la diversidad de tejidos que imponen diferencias de identidad a partir de los órdenes visuales de tramas, diseños, colores en cada una de sus vestimentas portadas y ostentadas en las realidades comunitarias del pasado y del presente.

Analizar tejidos, implica interpretar el sistema de sentido que ofrecen sus tejedoras, lo que quiere decir, desentrañar el quehacer creativo y el lenguaje visual de la feminidad andina contemporánea (Foto 5). En ese entendido, procuraré entender la relación que se establece entre tejido 


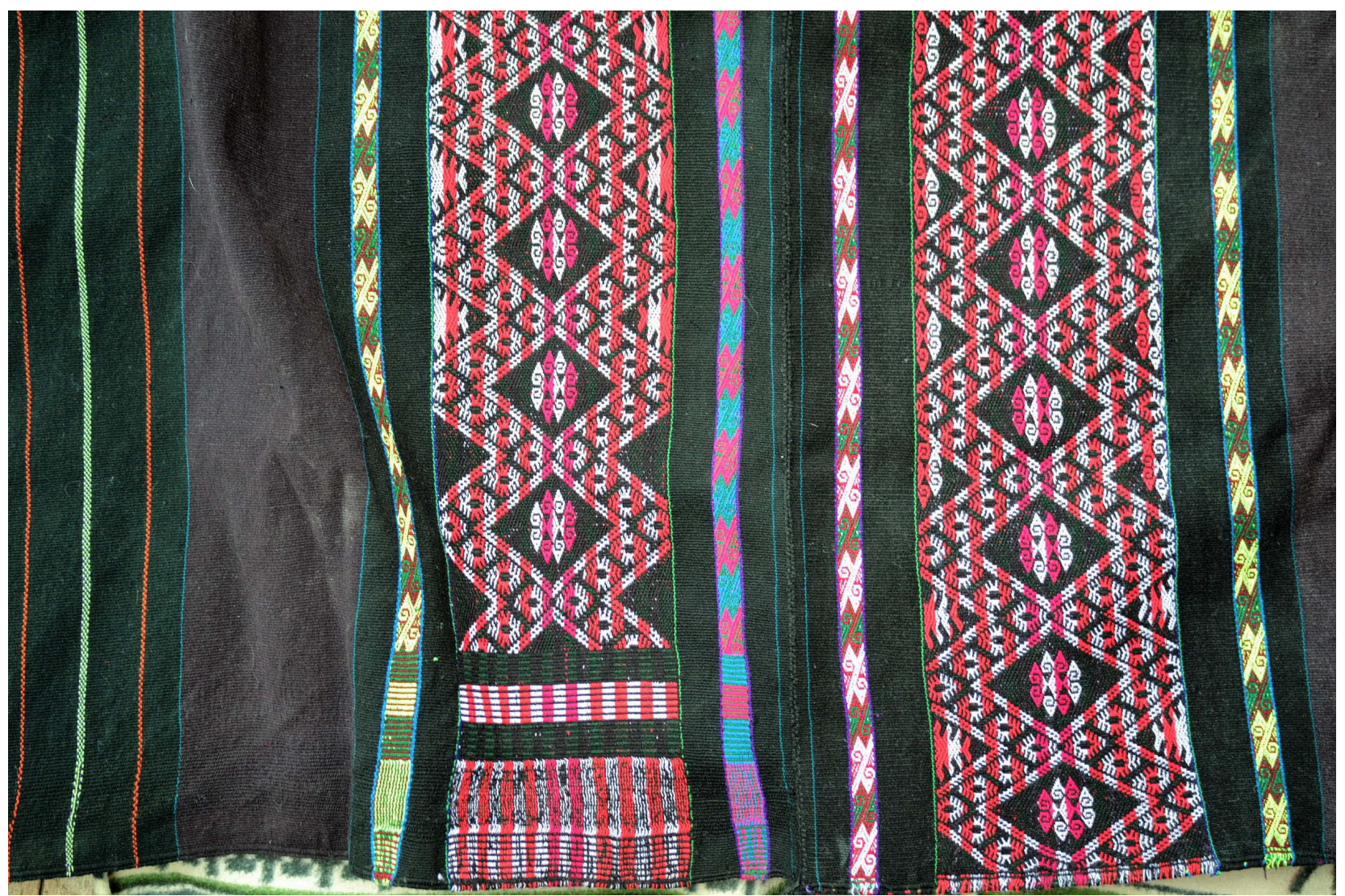

Fotografía 2: Detalle de la lliklla de Claudina. Fotografía de Verónica Auza Aramayo.
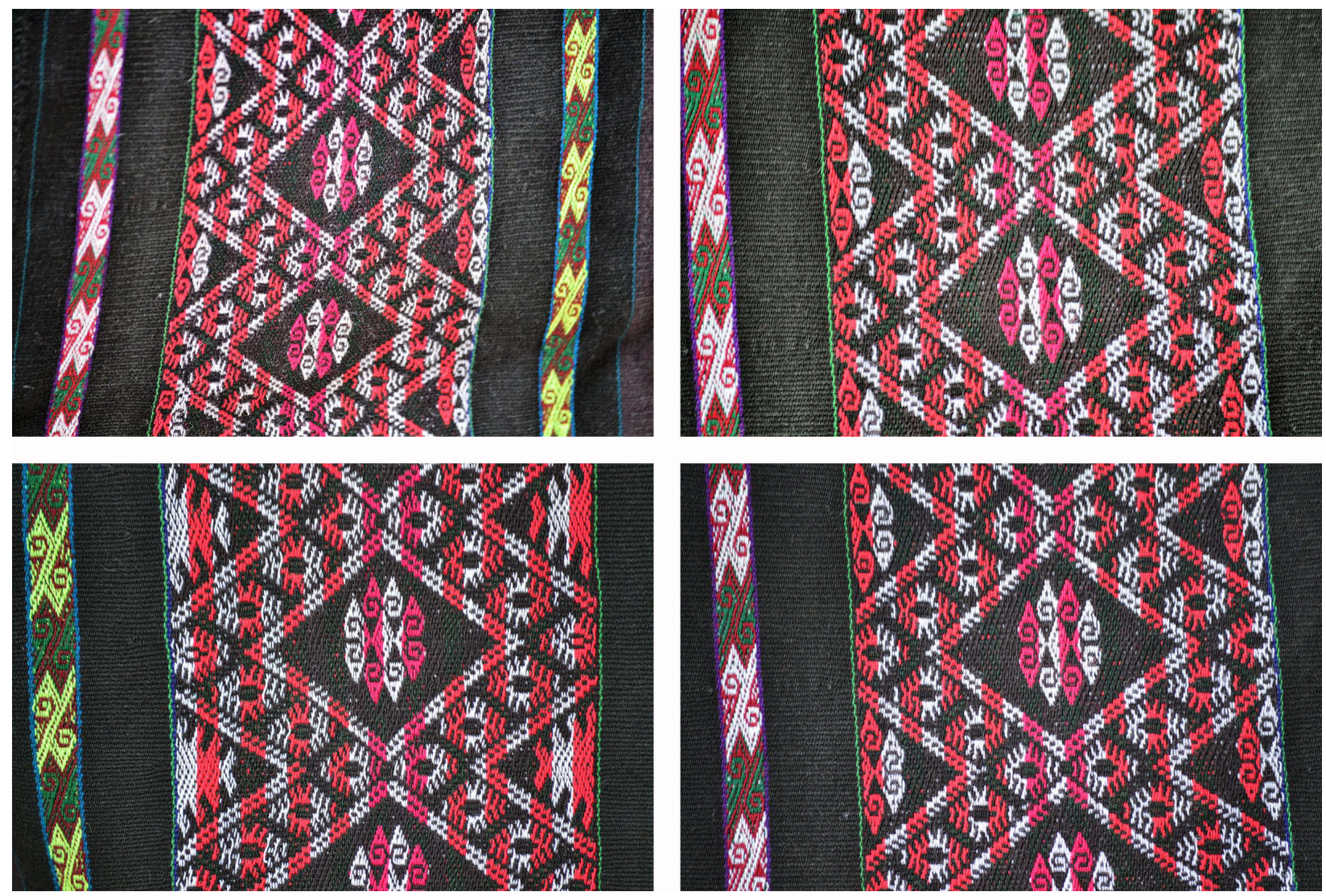

Fotografía 3: Cuatro detalles de la lliklla de Claudina. Fotografías de Verónica Auza Aramayo. 


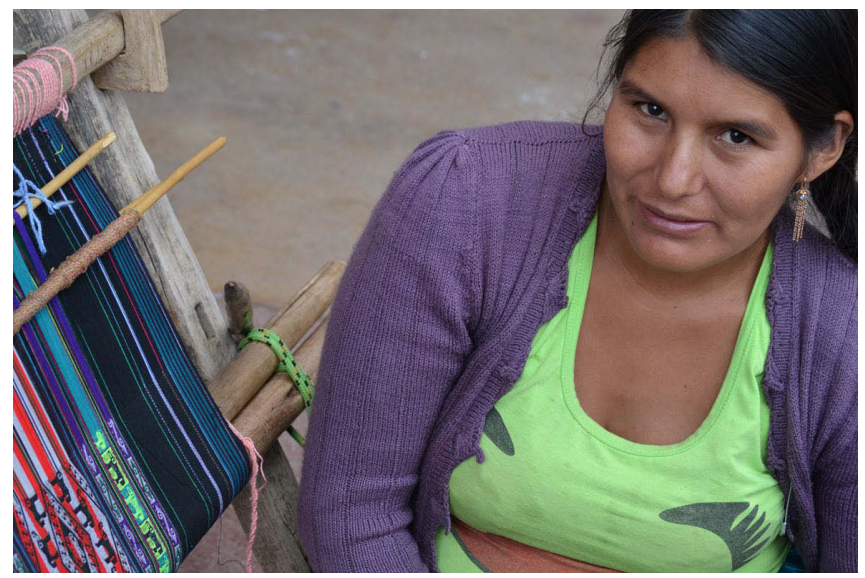

Fotografía 4: Claudina Torres y su telar. Fotografía de Verónica Auza Aramayo.

y territorio, en los textiles de Poroma, a partir de las conversaciones con Claudina Torres, de la comunidad de T'ula Pampa, Poroma. Claudina, tiene 29 años aprendió a tejer de niña con su mamá y a sus 14 años, tejió su primera lliklla para la fiesta de carnaval, desde entonces fue ganando destreza, actualmente Claudina puede tejer una lliklla en un mes. Cuando Claudina reflexiona sobre las formas y diseños que teje, me dice que siempre ha tejido así, "desde siempre así tejían, antes el color era así siempre”. Claudina, afirma: "llamero soy, como mis abuelos, somos llameros, mi abuelita, que no la conocí y mi abuelo de Macha venían, llameros somos, ellos han venido, hace tiempito ya, mucho tiempito ya, y me contaba mi mamá que en la Revolución Nacional (de 1952) los abuelos, grave han peleado por las tierras, bien dice que enfrentaba para ganar la tierra ahora de nosotros, desde Macha ha venido, cuando eran jóvenes, mucho había peleado mi abuelo para que las tierras de nosotros, sean nuestras". Como vemos, los abuelos de Claudina eran parte

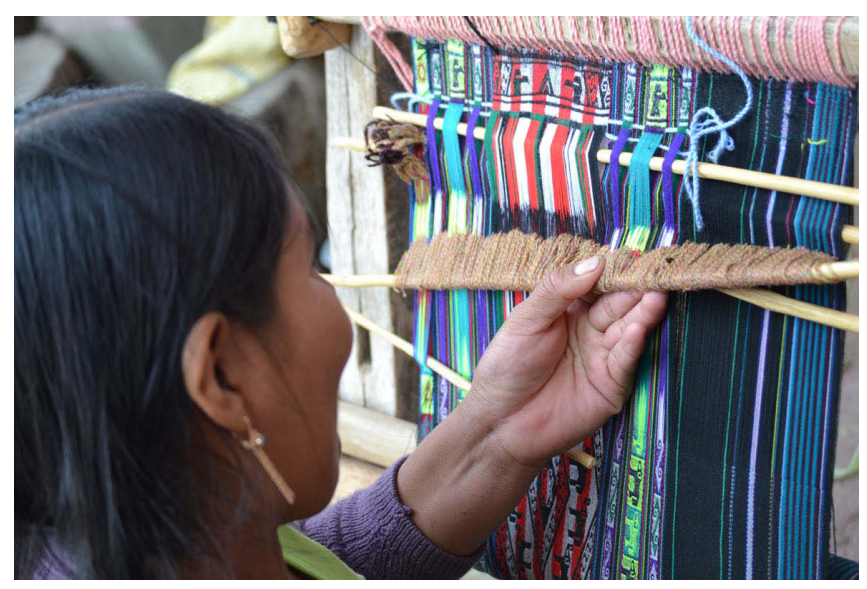

Fotografía 6: Detalle del telar de Claudia. Fotografía Verónica Auza Aramayo.

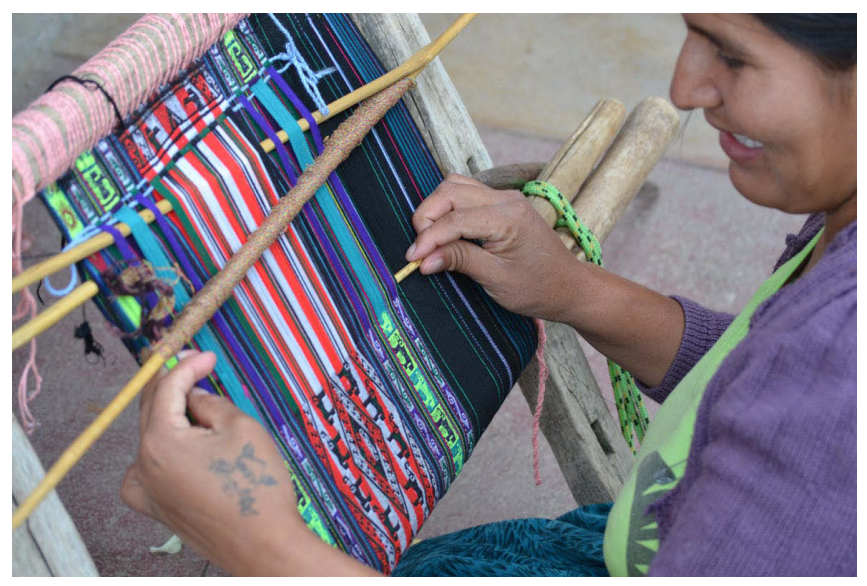

Fotografía 5: La técnica "kimsa pallay" de los Llameros. Fotografía Verónica Auza Aramayo.

de aquellos luchadores, aquellos caminantes nocturnos.

$\mathrm{Al}$ verla tejer a Claudina, noto la urdiembre copiosa de su lliklla, entonces, ella me explica: "Mira, si, cuanto más delgadito, pequeño es el hilo, se tarda más, mi mamá dice que mi abuela, tejía mejor que nosotros (Foto 6), pues harto hilo ponía, y acababa más bonito, más finito, mi mamá nunca podía tejer como mi abuelita, aunque ella sabe también... yo, entonces, siempre tejer así, un mini va de canto a canto, ves, el otro mini, solo está en el pallay... Ch'ulla, k'achito, kimsa, impar, de tres, se teje de tres, ¡ves!, así es bonito, así tiene que ser, otro siempre se pone, parte por parte, (aquí Claudina indica la diferencia entre pampa y pallay, estableciendo que esta distinción en los tejidos de Poroma no solo es visual, sino también técnica); así se teje, así siempre, así torcido, tiene que estar bien torcido los hilos (Foto 7), es un grosor medio, porque si es grueso peor se rompe y delgado cuesta mucho tejer... Nuestro pallay, chumpi, uskara, también, mi mamá le decía cochala pallay ch'ulla...

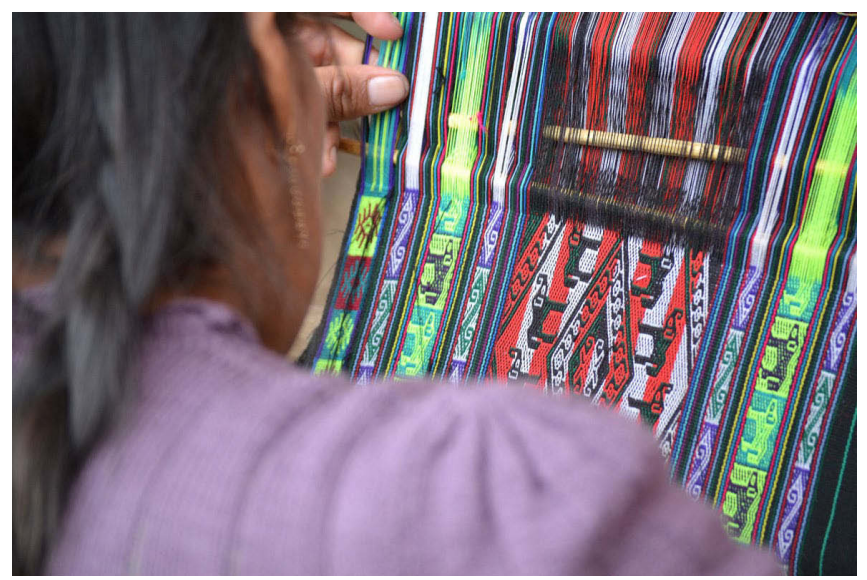

Fotografía 7: Detalle del kimsa pallay. Fotografía de Verónica Auza Aramayo. 

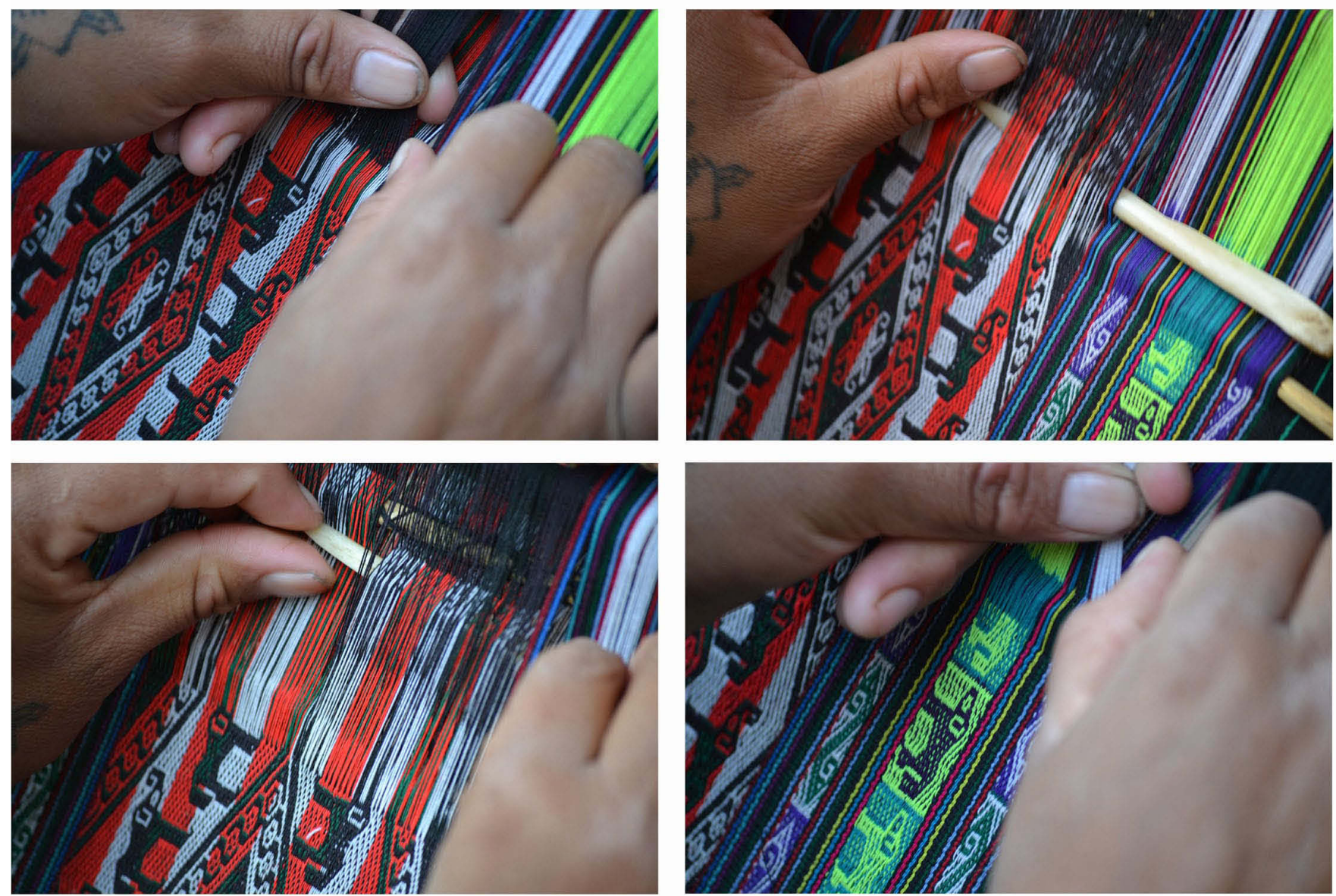

Fotografía 8: Cuatro detalles de los elefantes en los escenarios festivos de T’ula Pampa. Fotografías de Verónica Auza Aramayo.

Siguiendo este vasto repertorio visual femenino, la lliklla de Claudina es festiva por excelencia, lo que quiere decir que además de ser prolija en sus diseños y en sus colores, está destinada a celebrar la fecundidad, el poder de la preservación de la vida y el universo femenino fascinante del arte textil de Poroma. Como se puede apreciar en estas cuatro fotografías, vemos como Claudina ha incorporado en la trama festiva de su pallay a elefantes, que este año hace parte de su diseño para celebrar los bailes del carnaval. Además, en esta prenda podemos apreciar la complejidad técnica del kimsa pallay con prolíferas bandas diseñadas contemporáneas que evocan ese pasado de los antiguos caminantes llameros en el presente colorido del carnaval en T'ula Pampa.

Claudina, nos dice que los tejidos siempre han sido así en sus diseños, estructuras cromáticas y sentidos visuales (técnica, formas y creatividad) particularmente intrincados (Foto 8), puesto que su pallay llevan tres colores, lo cual implica una técnica singular, puesto que necesita dos hilos madres, uno para toda la trama y el adicional solo va en el pallay de la pieza, es este hilo madre adicional, el que posibilita tramar la urdiembre del pallay con tres colores y así distinguir el resto del textil que solo lleva dos.

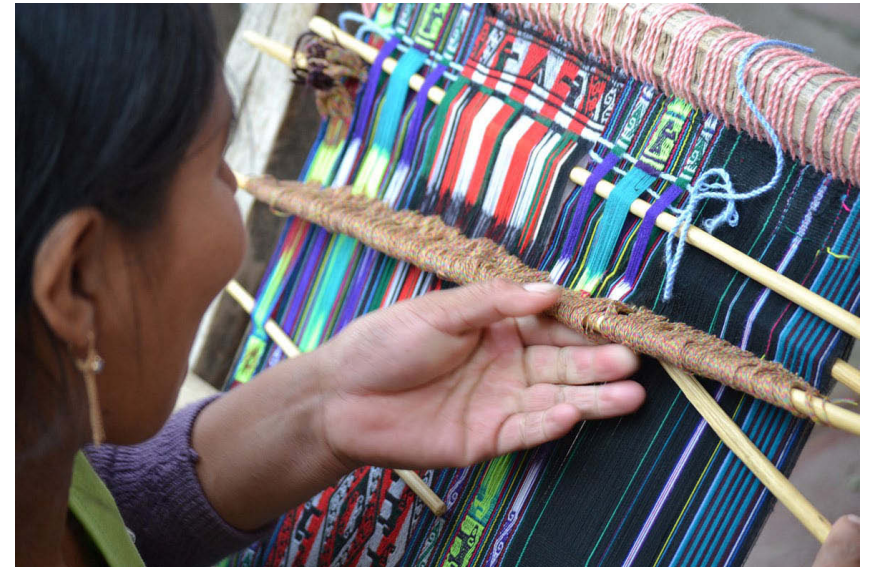

Fotografía 9: Detalle de la técnica del kimsa pallay de los llameros. Fotografía de Verónica Auza Aramayo.

Como ya he mencionado Poroma, siendo zona valluna, se destaca por autonombrarse "llameros", denominación o concepción que nos remonta a una dinámica espacial notable en sus alcances, la de los trajines de los llameros y sus caravanas desplazadas en extensos kilómetros de norte a sur 

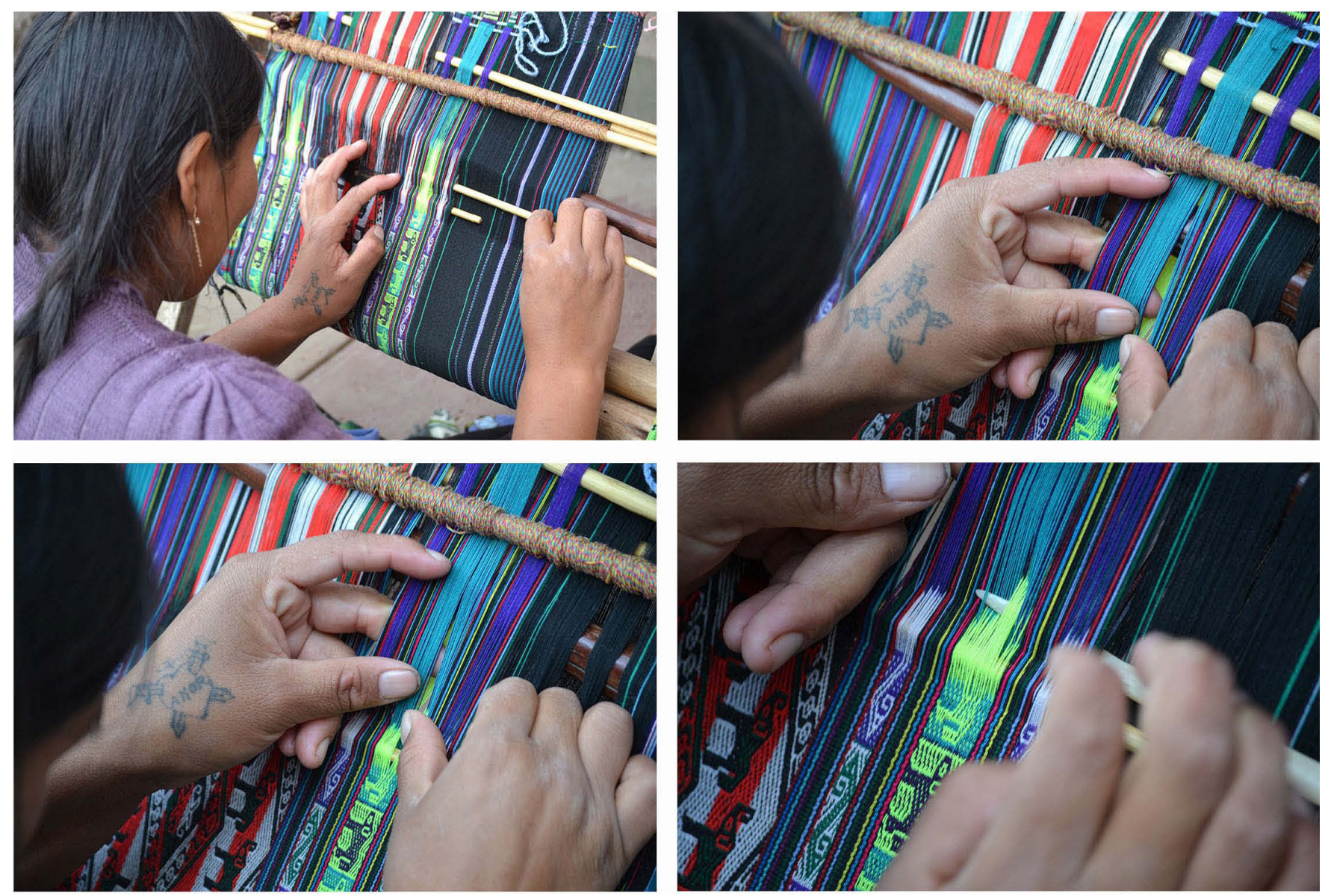

Fotografía 10: Cuatro detalles de la técnica textil de las tejedoras de Poroma. Fotografías de Verónica Auza Aramayo.

por el territorio andino (Foto 9). Seguir siendo "llameros" implica una identidad en la cual de cierto modo no ha dejado de latir la evidente presencia de la Puna que, a su vez, nos remite a aquellas prácticas donde el trajín trazaba mapeos culturales, que desde épocas prehispánicas hicieron a la vida andina y que actualmente todavía perdura como imaginario cultural de esta identidad étnica.

En fin, me atrae particularmente este contrapunto (Foto 10) que subyace en esta distinción étnica, cargada de entrada de una compleja dinámica multiétnica que sucede y que sucedió en estas comunidades; viendo los diseños textiles, considero que el entresijo de sus signos también evocan de un modo particular esa multiplicidad y superposición de este modo de configuración territorial y étnico (Foto 11), lo cual claro, aborda el complejo tema del territorio andino y el sentido que las tejedoras brindan con sus tejidos.

Abordar a las tejedoras de las comunidades de Poroma, con las cuales he establecido contacto, me permite reflexivamente, atar mi interpretación teórica desde el abordaje semiótico de sus textiles (Foto 12) y todo lo que sus signos contienen del modo de habitar y significar su territorio. Sin duda, este ensayo es parte del campo de conocimiento

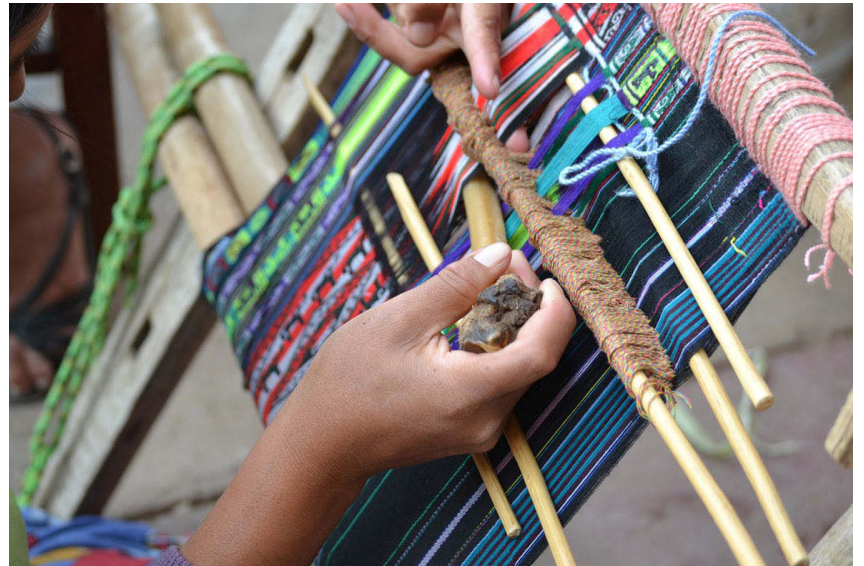

Fotografía 11: En Poroma, el pallay se teje de tres. Fotografía de Verónica Auza Aramayo.

que comprende el léxico que nos ofrecen los textiles, como "textos" (Verónica Cereceda, 2010), con sus mensajes precisos, sus convenciones, sus unidades mínimas, el porqué de sus órdenes cromáticos y la figuración de sus diseños; en definitiva, mi análisis procura acercarse a la 

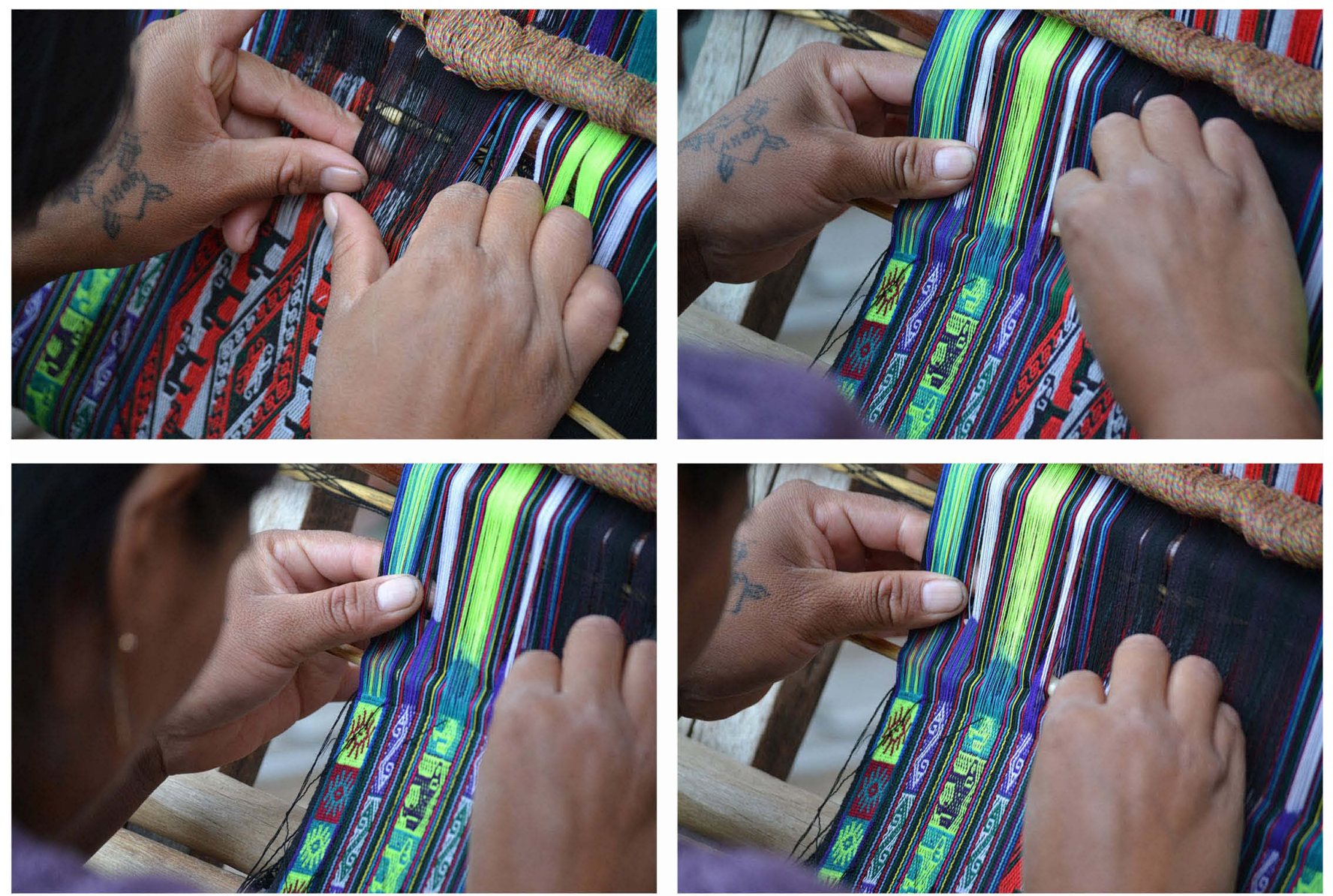

Fotografía 12: Secuencia de cuatro detalles del arte de tejer de Claudina. Fotografías de Verónica Auza Aramayo.

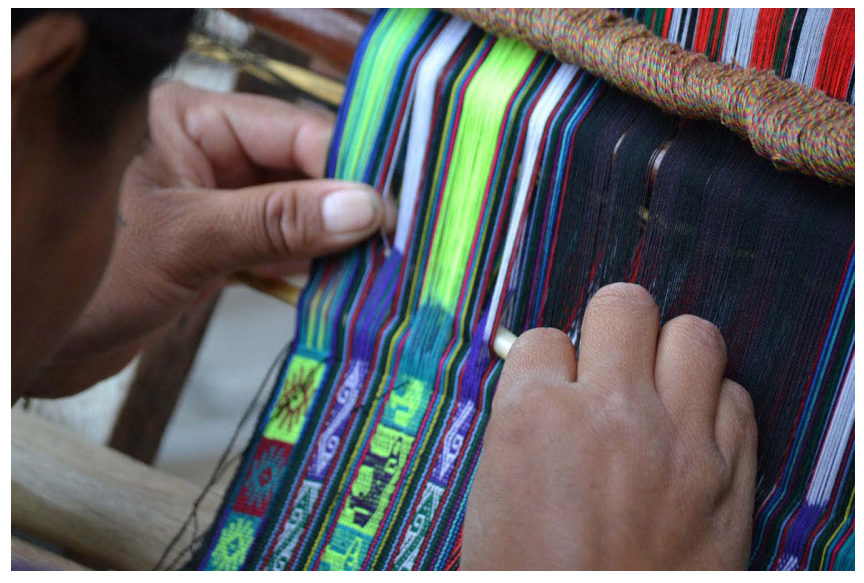

Fotografía 13: Se teje de tres. Fotografía de Verónica Auza Aramayo.

significación textil del cosmos y de la vida, a este lenguaje no letrado que no cesa de expresarse desde sus contextos más íntimos y sensibles.

En ese sentido, las líneas que seguirán, por un lado, serán un intento para comprender el cómo a pesar de la marginalidad y casi desaparición de textiles y tejedoras (Fotos 13, 14), ambos, siguen manteniendo y haciendo efectivo el

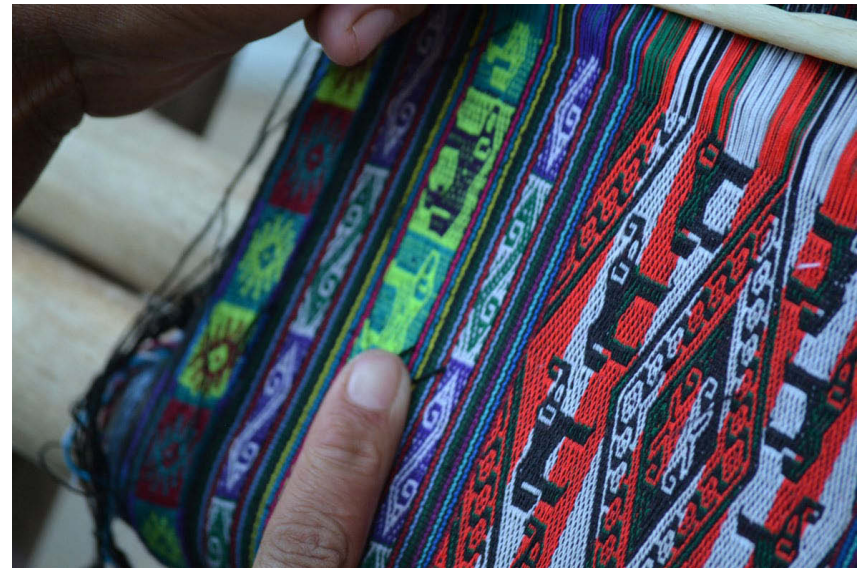

Fotografía 14: Se teje de tres... Fotografía de Verónica Auza Aramayo.

modo de hacer habitable el espacio y de dotar de sentido de identidad a un territorio desde un lenguaje emotivo, visual y femenino.

Cada una de las imágenes, muestra como los hilos de la trama de los textiles de Poroma (Fotos 15, 16), conllevan en su orden cromático, en su técnica y su diseño, los caminos, lo recorridos que se llevaron a cabo a lo largo de los 


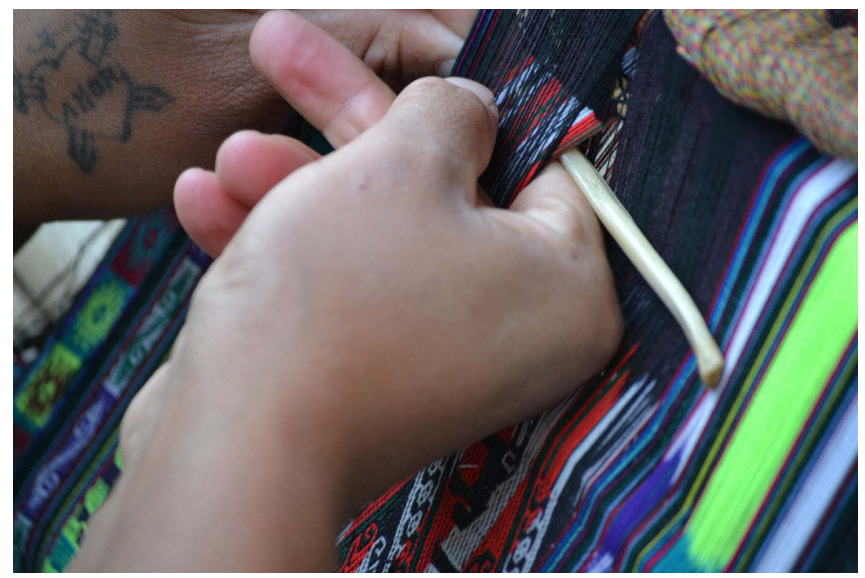

Fotografía 15: Los hilos del kimsa pallay. Fotografía de Verónica Auza Aramayo.

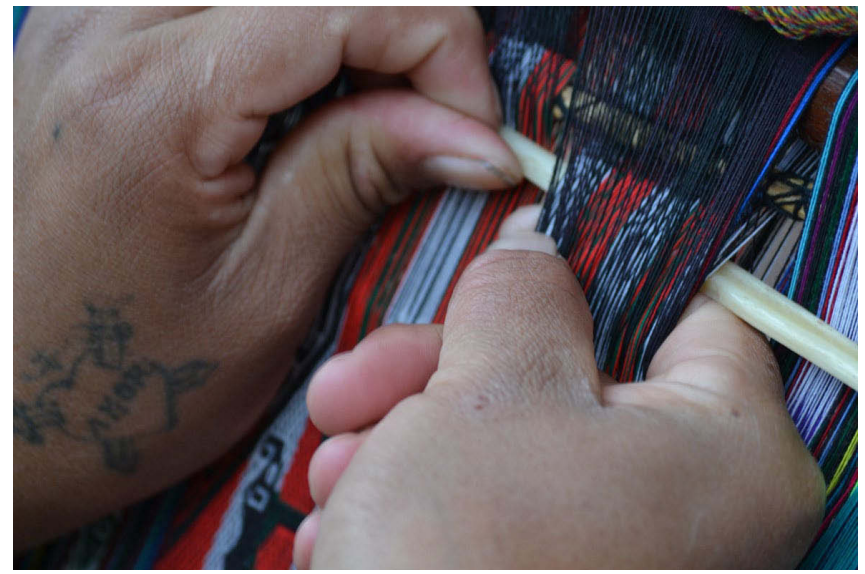

Fotografía 16: Los hilos de la puna al valle. Fotografía de Verónica Auza Aramayo.

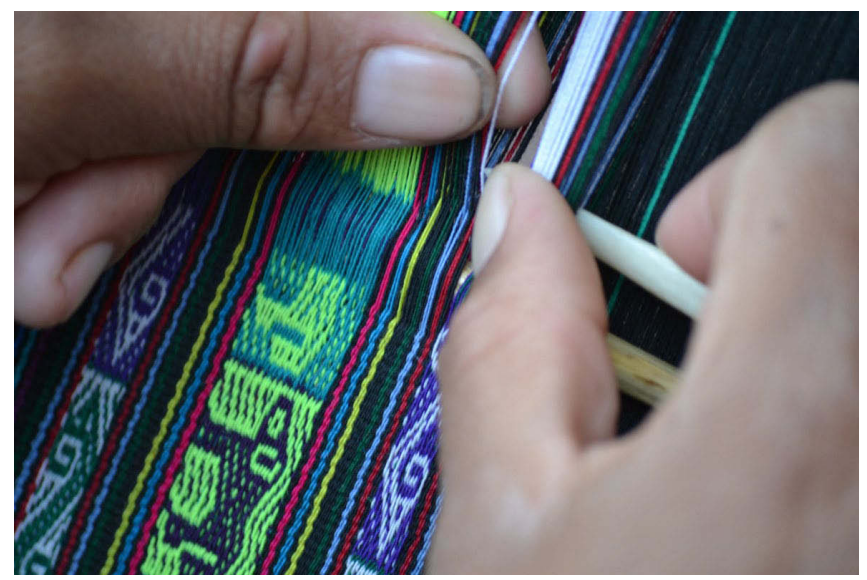

Fotografía 17: De la puna al valle: el diseño textil de Poroma. Fotografía de Verónica Auza Aramayo.

tiempos para pasar de habitar la puna al valle (Foto 17, 18, 19). La técnica del kimsa pallay, ese tejer de a tres, implica, una técnica que requiere dos hilos madres para tramar la

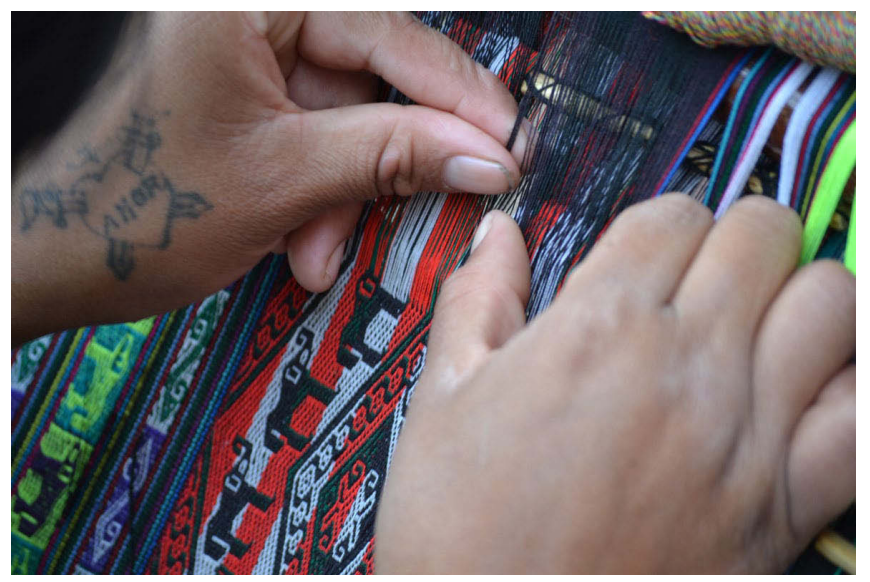

Fotografía 18: De la puna al valle... Fotografía de Verónica Auza Aramayo.

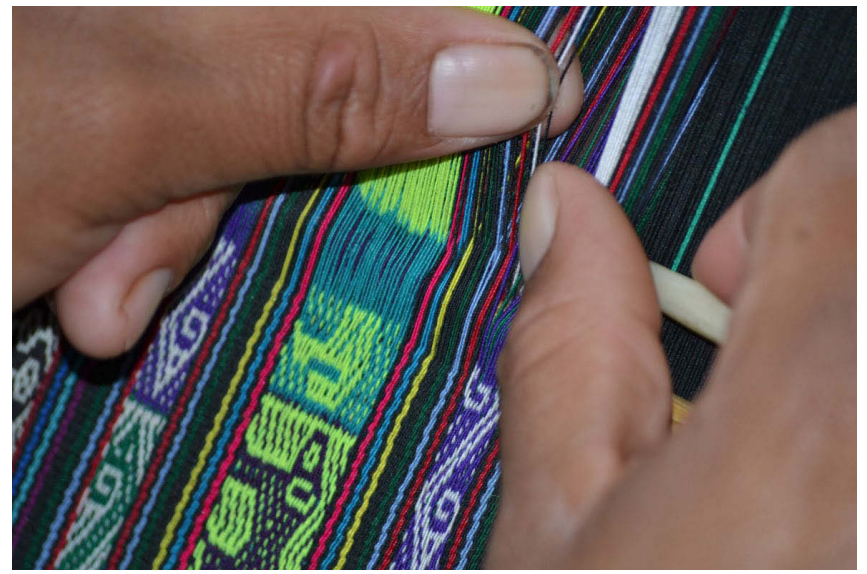

Fotografía 19: De Macha a T'ula Pampa. Fotografía de Verónica Auza Aramayo.

urdiembre, esto nos habla de una cultura textil, desde donde las tejedoras de Poroma, nos expresan una forma de habitar el territorio, el mundo, con un principio esencial de tres, la presencia de estos dos hilos madres, nos dan cuanta que solo es posible tejer el pallay así, no de otra manera, pues como lo recalca Claudina, "siempre se teje de tres", es esta la configuración textil y cultural que distingue los tejidos de Poroma, al interior de los Andes.

De ese modo, se comprende como las formas de desplazarse y ocupar el espacio y el territorio en los Andes (Fotos 20,21 ), tiene un impacto en el lenguaje visual de los diseños textiles andinos, puesto que cada distinción textil de un modo u de otro, marca su diferencia en el espacio, su diferencia de diseño, orden cromático y una semántica, la cual con el apoyo de las técnicas que, en el caso de Poroma, implica dos hilos madres en el pallay de las prendas (Foto 22), logran construir y trasmitir su mensaje étnico, su "texto" étnico, como bien señala Verónica Cereceda (2017). Pues bien, bajo este kimsa pallay podemos advertir el lenguaje 


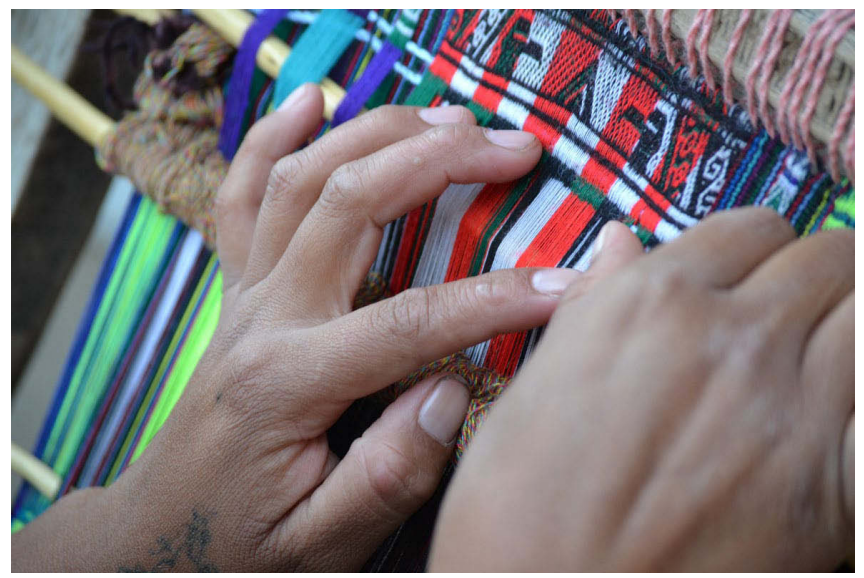

Fotografía 20: Los lenguajes territoriales del textil. Fotografía de Verónica Auza Aramayo.

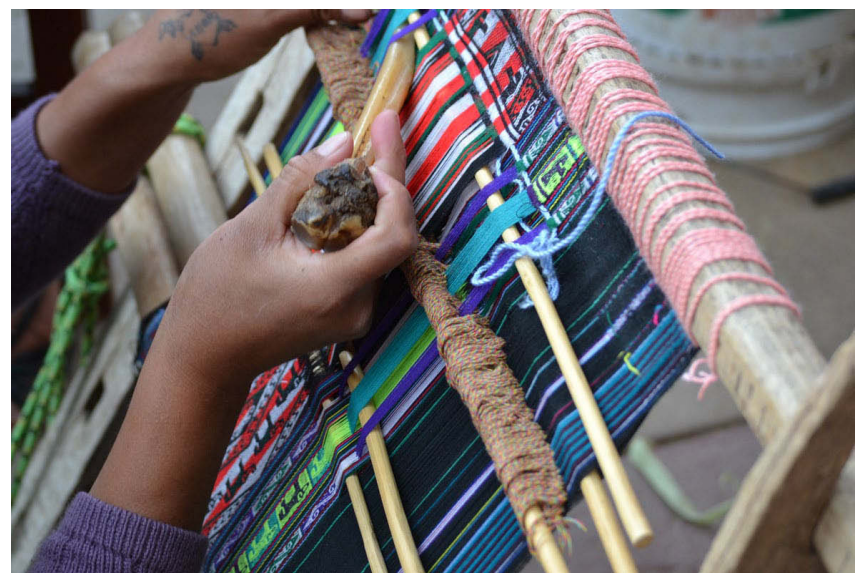

Fotografía 21: Los dos hilos madres del pallay de los tejidos de Poroma. Fotografía de Verónica Auza Aramayo.

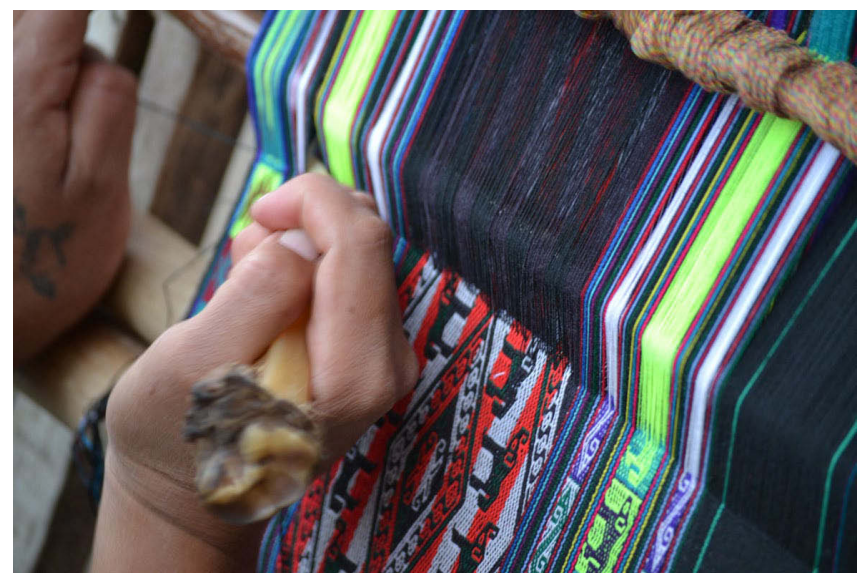

Fotografía 22: Los de los hilos madre del pallay de Claudina. Fotografía de Verónica Auza Aramayo.

visual (Foto 23), la gramática textil que los tejidos de Poroma trasmiten con el arte textil que a lo largo de los tiempos, las tejedoras y sus culturas han venido desarrollando

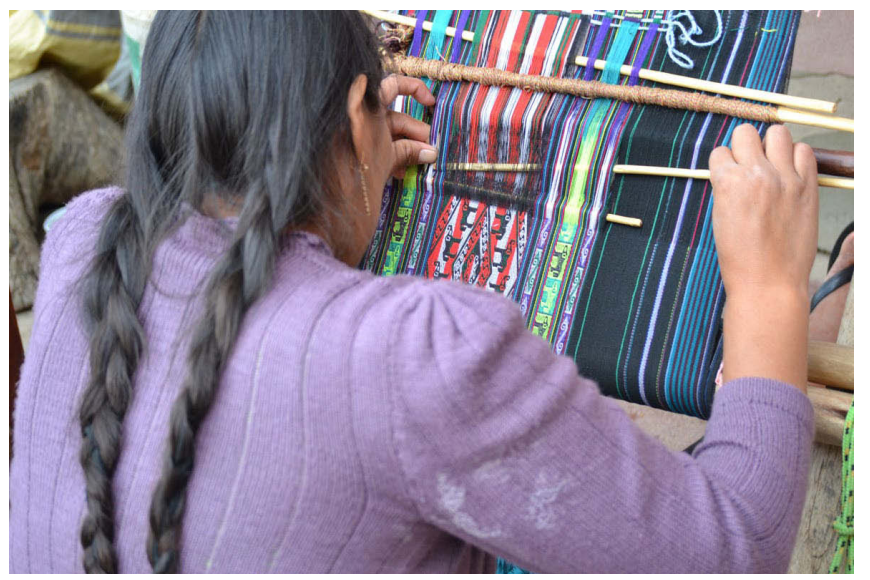

Fotografía 23 Urdiembre y trama del kimsa pallay de la lliklla de Claudina. Fotografía de Verónica Auza Aramayo.

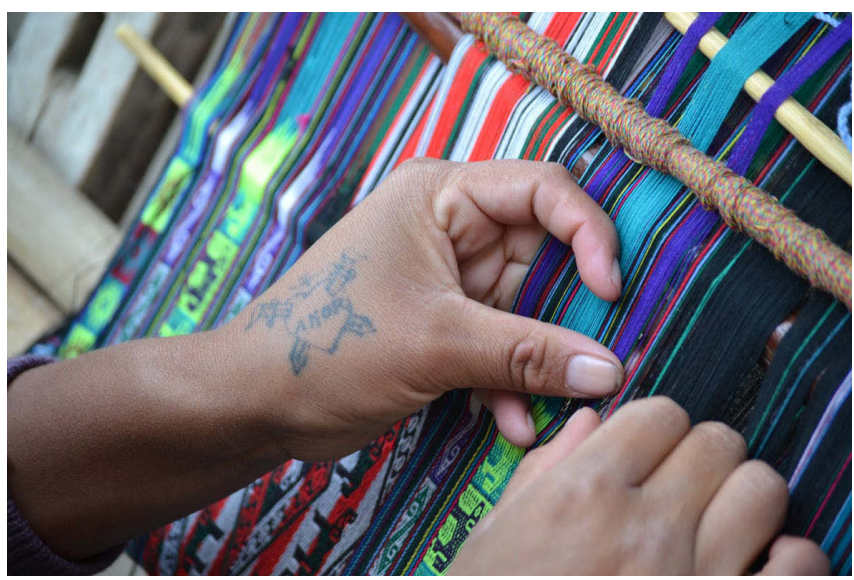

Fotografía 24: Detalle de la lliklla de Claudina. Fotografía de Verónica Auza Aramayo.

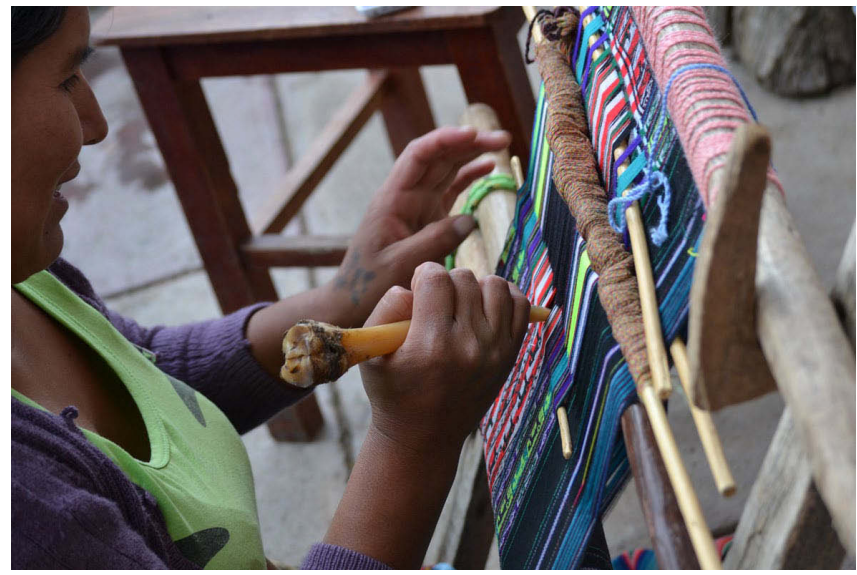

Fotografía 25: Claudina tejiendo su lliklla para el carnaval. Fotografía de Verónica Auza Aramayo.

habitando el territorio desde las pautas visuales y los distintivos repertorios de cada uno de los textiles andinos (Foto $24,25)$. Hecho que también puede ser pensado bajo una 


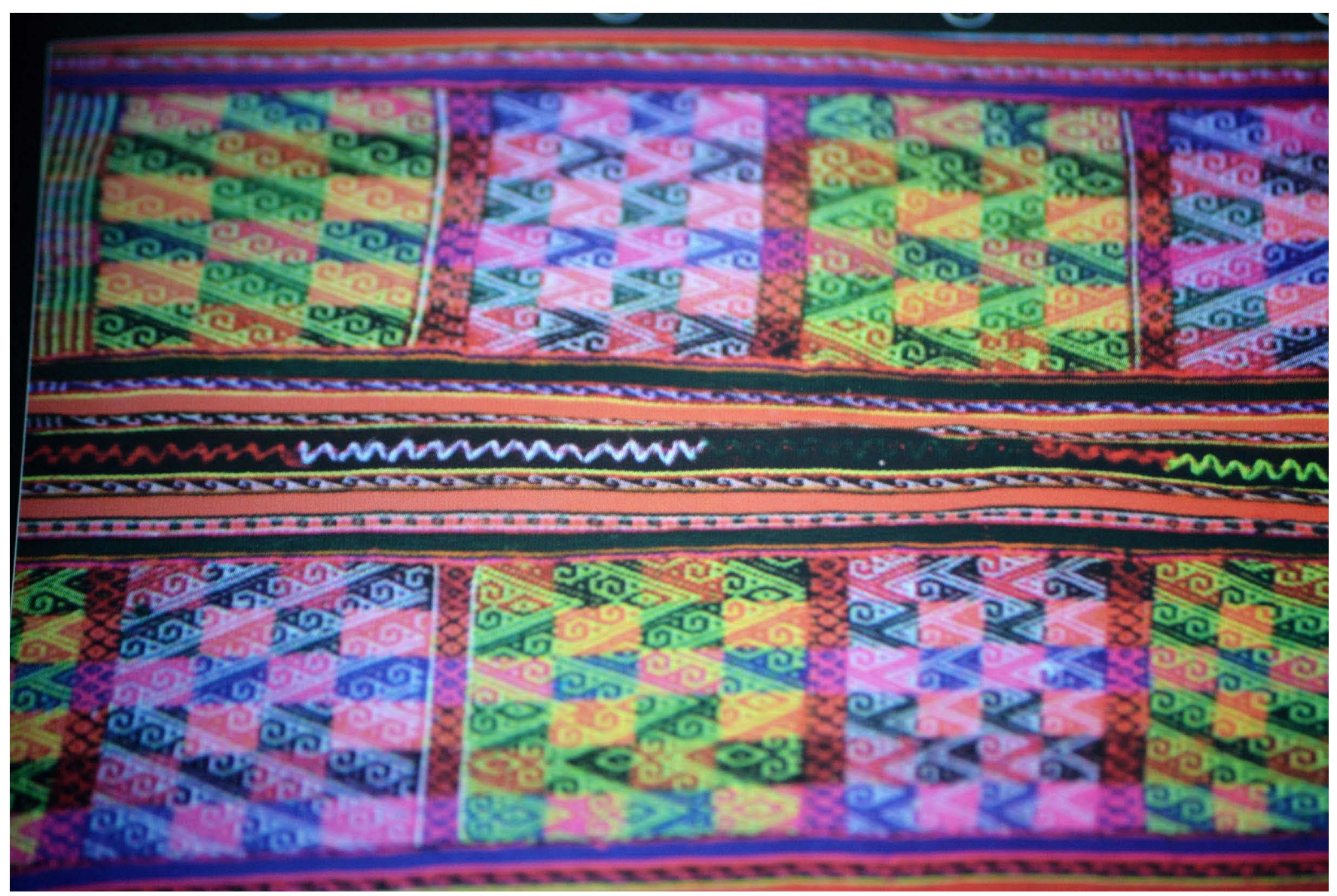

Fotografía 26: Detalle del diseño de Aywira de la lliklla de Viru Viru, Poroma. Fuente: Diseños de los textiles Poroma. Investigación y fotografías. ASUR, 2010. Pág. 93.

mirada arqueológica, que nos recuerda como las palabras de creación de Viracocha que impartían una distinción de vestimenta y con la diversidad textil que hoy en día, supone, como también lo señala, el sistema territorial de archipiélago vertical que nos legó Murra (1975), pues, en definitiva, en los Andes, se habita el territorio desde los lenguajes plásticos y la semiótica visual de los textiles.

\section{Aywira: un diseño textil de los andares de los llameros.}

De manera genérica, el diseño que más resalta y distingue a los tejidos de Poroma es el aywira, la mayoría de los diseños son nombrados así por las tejedoras. Según Ludovico Bertonio: "aywiratha, significa: desviarse un poco de donde están"; "aywiracatha: ir contra la voluntad del capitán, o pastor”. Los diccionarios más contemporáneos, señalan que aywira significa caminar o ir en grupo, andar en conjunto de un lugar a otro; andar a otro lugar sin dirección.

Para las tejedoras de Qaqachaca, aywira es una figura textil del camino celestial de las llamas (Arnold: Hilos sueltos: 309), curiosa denominación, ya que la gente de
Poroma se autonombra como "llameros". De esa manera, el diseño de Aywira (Foto 26), es un diseño textil que teje y representa muy bien los andares de los llameros, andares que resultan un movimiento contrario al establecido, un tanto desviado, que oscila de un lugar a otro en franca deriva, siguiendo, en pero, el camino celestial de las llamas.

La técnica de los textiles de Poroma, también dan cuenta de la dinámica étnica que la definió a los hilos del aywira a través de la historia, puesto que la parte de sus pallay lleva dos hilos madres, lo cual establece una trama doble y hasta triple en sus ejes principales del diseño, ello claramente expresa aquello que Sophie Desrosier (1992) concibe como un sentido o una ideología volcada en la técnica (Foto 27). En la imagen se ve una lliklla de la comunidad de Viru Viru, con diseños ch'uritos de 4 pares de hilo y Nawi aywira de 90 pares, con bordes linku y divisiones jark'achis o k'utus.

Siguiendo el argumento de Desrosier, sin duda, la singular característica técnica empleada por las tejedoras de Poroma para tejer sus llikllas, tiende a confirmar la existencia implícita del kimsa, el hilo ch'ulla que distingue su trama como el código textil de T'ula Pampa y su trama nos permite 


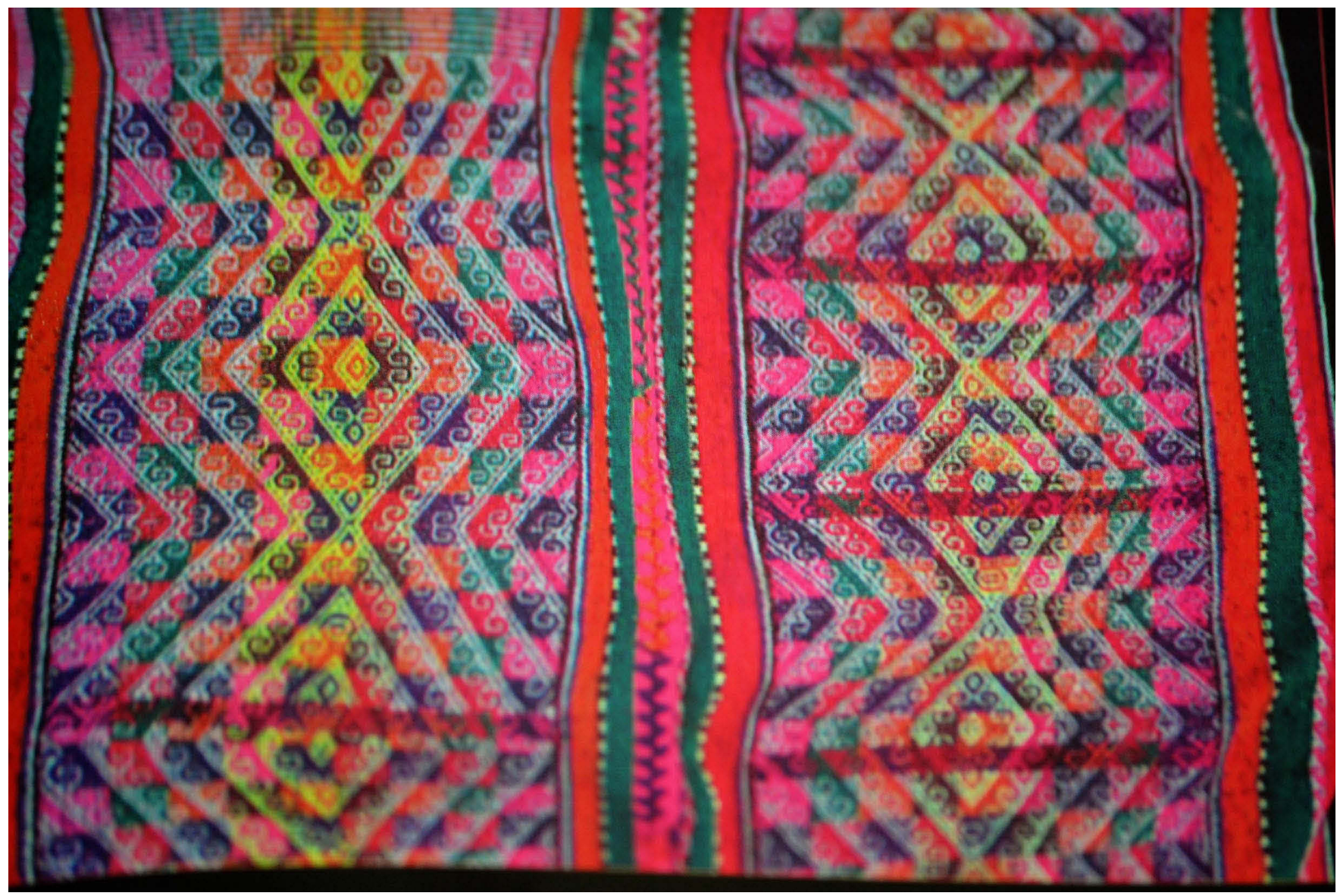

Fotografía 27: El diseño aywira de la lliklla de Viru Viru, Poroma. Fuente: Diseños de los textiles Poroma. Investigación y fotografías. ASUR, 2010. Pág. 93.

comenzar a interpretar su sistema y mensaje étnico como aquel que rompe la dualidad o el esquema dualista de faz urdiembre y con ello, transmitir ese solo "ser viviente" en cursivas, el resto del texto no de los caminos, de los desplazamientos que los antiguos luchadores realizaron para dotar de un territorio a su cultura nómada; así la técnica de Claudina ofrece todas las construcciones simbólicas que los llameros vaciaron en sus tramas y urdiembres para dotar sentido al espacio y habitar este valle con aires de la otrora puna que los cobijaba.

\section{A modo de conclusión.}

Pensar en la transcendencia del uso y apropiación del espacio en el mundo andino, nos permite comprender el paso de la puna al valle en los tejidos de Poroma, que traen al ahora, la distancia temporal, y al mismo tiempo los andares y los desplazamientos que los abuelos, aquellos caminantes de la noche desde la puna potosina, en franca clandestinidad, idearon principios comunitarios para volver al territorio con un sentido propio. Fueron, estos abuelos y también las abuelas las que idearon sentidos de pertenencia en sus desplazamientos, cual dinámicas nómadas, replanteando su identidad étnica, en procesos multiétnicos, donde el tercero, el otro, no puede estar excluido, todo lo contrario, como dice Claudina "se teje de tres", como se vive y convive en las comunidades contemporáneas de Poroma, convirtiendo a su expresión pallay, en un kimsa pallay desde el cual observamos lo que dice Bertonio del diseño aywira, bañado con estrellas, con luz de noche, como aquel umbral del cielo de la puna Macha y la oscuridad encendida del mensaje jalq'a, llevándonos en esta trama, aquellos andares, de llameros, de caravanas, del control vertical (Murra, 1975), donde las comunidades lucharon, resistieron, y en cierto sentido "se desviaron" para no perder su territorio. Todo ello late y lo vemos expresado en la diversidad étnico cultural de Poroma y en las tramas de los tejidos de Duraznillo, Viru Viru, T'ula Pampa.

Mismo lenguaje visual que enlaza los órdenes cromáticos del amarillo guerrero de Pocoata, el blanco y rojo 
intercalado de cultura luchadora de Macha y los diseños estrellados, brillantes en sus destellos como las altas punas desde que emprendieron el viaje y la decisión de quedarse para habitar un valle que traía en sus estribaciones el legado de los abuelas de los abuelas... viendo esta singular construcción de sentido visual y de distinción textil, se puede seguir estos caminos y devenires que desde la técnica y los recorridos emprendidos, las llikllas pasaron y se detuvieron en el signo de aywira, del jatun chas'ka, del churasqa, para llegar a la nomadología actual de elefantes y perros que acompañan su andar en un espacio que a pesar de ser accidentado encuentra su lugar, su eje, su hogar, y podemos convenir que todavía, hoy en el mundo andino textilmente se habita y textilmente la identidad es vestida de color, de sentido, de diseño y de signos.

Los textiles son una imagen del territorio, igualmente podemos considerar el lenguaje visual y la estética de la técnica textil como un modo de territorializar el estar en el mundo, un tejido a los ojos andinos es una fábrica de sentidos que forjan las identidades en el espacio, solo ahí, los hilos, sus tramas, sus colores y su estructura pueden amplificar visualmente el espacio y configurar territorios.

Los tejidos hacen nacer la imagen de un mundo y nos permiten interrogar en ellos los modos de ser y estar en el territorio que se habita... de la puna al valle, sí, pero bajo la condición histórica de valorar el nombre de sus ancestros, la gente de Poroma son «llameros» y no dejaron de ostentar ese afecto por las alturas, finalmente, éstas son su origen, su principio, su nacimiento cultural y es en el tejido, donde este intrincado principio se colma y se explaya bajo los kimsa pallay, porque para esta cultura siempre se teje de tres.

En definitiva, los textiles en el mundo andino no se reducen a ser objetos bellos en sí mismos, ya que todo textil transmite, evoca y promueve un sentido de identidad, de poder, de prestigio, de afecto $\mathrm{y}$, como hemos podido ver, de territorialidad, de ser en el espacio. Es por ello, que es axial interpretar el devenir y las transformaciones de los diseños y de los órdenes cromáticos concibiendo sus procesos de territorialidad en cada mirada sobre esta etnología del arte, sobre el alcance de cada una de sus fuerzas vivas, mágicas y espaciales que los tejidos tienen el don de expresar.

El paso de la puna al valle, nos exige analizar esos caminos étnicos por donde los pueblos andinos libraron su lugar en el mundo, trajines, desplazamientos por el territorio que desde tiempos precolombinos se fueron sucediendo y, como se ha visto en el caso de Poroma y de sus textiles, podemos atisbar la forma en que los textiles traducen la manera de hacer habitable los espacios, cuando nos enfrentamos a leer y entender los signos textiles y sus variedades de diseños y ordenes cromáticos que a lo largo y ancho del mundo andino se fueron explayando a través de nuestra historia. Hemos visto como léxico textil es también un léxico territorialque creo que es posible remontar a los estudios y análisis de los textiles arqueológicos.

Para terminar, considero que los tejidos de Poroma traducen la fuerza y la emoción estética viva que en los Andes, desde tiempos inmemoriales, ha tenido la virtud de marcar distinciones textiles en su ocupación del espacio y del territorio. Como hemos visto, los diseños textiles de Poroma, evocan el paso de Macha a T'ula Pampa que los abuelos de Claudina realizaron en su historia, recorrido territorial que los llameros de Potosí libraron para establecerse en el valle de Poroma y que sus tejedoras le crearon un distintivo diseño textil. Mi aporte radica en llevar esta lectura a los estudios de la exhaustiva arqueología textil existente, y así ir ampliando significativamente nuestra mirada visual y nuestro repertorio histórico cada vez que profundicemos el análisis de los textiles desde sus modos de tejer los diferentes desplazamientos y dominios del espacio que las diferentes textiles evocan y actualizan en todos sus devenires comunitarios que al construir y apropiarse del territorio, hacen que éste sea habitable y se convierta en signo de identidad. Tras este breve análisis, pienso que las tejedoras de Poroma y sus tejidos, exponen francamente el campo de sentido de la dupla: textil y territorio, campo que implica el devenir histórico de la puna al valle tejido en los intrincados diseños del kimsa pallay, a la vez novedosos y a la vez ancestrales, pues en ellos, apreciamos el aywira de Bertonio, los andares nocturnos y clandestinos de los abuelos y el desvío festivo del jatun chaska y de los elefantes para el carnaval que se mueven oscilantes en la lliklla de Claudina.

\section{Bibliografía.}

Arnold, Denise, Yapita, Juan de Dios y Elvira Espejo.

2007. Hilos sueltos: Los Andes desde el textil. La Paz: ILCA y Plural.

Bertonio, Ludovico.

1984 (1612). Vocabulario de la lengua aimara. Cochabamba: Edición Facsimilar Cochabamba, CERES.

Cereceda, Verónica.

2017. De los ojos hacia el alma. La Paz, Plural editores.

(Santiago Pórcel y Román Flores).

2010. Diseños de los textiles de Poroma. Sucre: ASUR.

- Prólogo. (Santiago Pórcel, Román Flores y Juan

Arancibia).

2010. Poroma: Composición étnica y culturas. Sucre: ASUR. 
Desrosiers, Sophie,

1992. "Las técnicas del tejido ¿tienen un sentido? Una propuesta de lectura de los tejidos andinos” En: Revista Andina. Tejido Andino: Pasado y Presente (I). Año 10 No 1, julio de 1992. Pp.: 7-46.

1997. "Lógicas textiles y lógicas culturales en los Andes" En: Bouysee-Casagne, T (comp.) Saberes y memorias en los Andes. In Memoriam Thierry Saignes. Lima: CEDRAL-IFEA. Pp.: 325-349.

Dransart, Penélope.

1996. “Iconografía en el arte textil del sur del Perú y del norte de Chile: Algunas consideraciones sobre las formas figurativas y abstractas". Ponencia presentada a la Conferencia "Bodas de Oro en el Museo de Ica.

Gisbert, Teresa, Martha Cajías y Silvia Arze.

2006. Arte Textil y Mundo Andino. 3era edición. La Paz: MUSEF/PLURAL/Embajada de Francia en Bolivia.

Guamán Poma de Ayala, Felipe, (1615).

1980. El primer Nueva Crónica y buen gobierno. Ed. John Murra y Rolena Adorno. México: Siglo XXI editores.
Murra, John.

1975. Formaciones económicas y políticas del mundo andino. Lima: IEP.

Nicolas, Vincent.

2015. Los ayllus de Tinguipaya. Ensayo de historia a varias voces. La Paz: Plural editores.

Rostworowski, Maria.

200o. Estructuras andinas del poder. Lima: IEP.

Saignes, Thierry.

2015. Desde el corazón de los Andes. Indagaciones históricas. La Paz: Plural editores y IFEA.

Silverblatt, Irene.

1990. Luna, sol y brujas. Género y clases en los Andes prehispánicos y coloniales. Cusco: Centro de Estudios regionales andinos "Bartolomé de las Casas". 